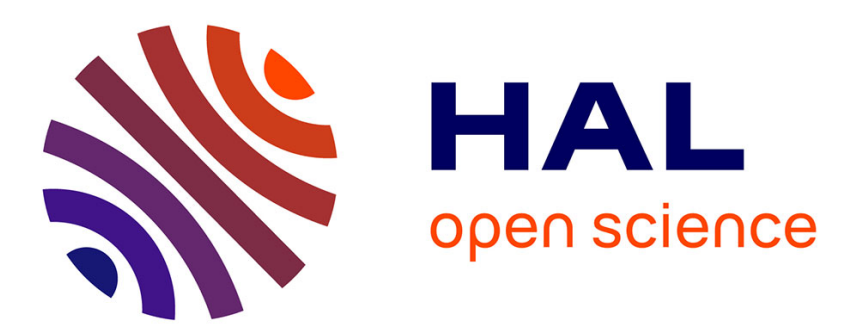

\title{
Environmental determinants of leaf litter ant community composition along an elevational gradient
}

\author{
Mélanie Fichaux, Jason Vleminckx, Elodie A Courtois, Jacques Delabie, \\ Jordan Galli, Shengli Tao, Nicolas Labrière, Jérôme Chave, Christopher \\ Baraloto, Jérôme Orivel
}

\section{To cite this version:}

Mélanie Fichaux, Jason Vleminckx, Elodie A Courtois, Jacques Delabie, Jordan Galli, et al.. Environmental determinants of leaf litter ant community composition along an elevational gradient. Biotropica, 2020, 10.1111/btp.12849 . hal-03001673

\section{HAL Id: hal-03001673 \\ https://hal.science/hal-03001673}

Submitted on 12 Nov 2020

HAL is a multi-disciplinary open access archive for the deposit and dissemination of scientific research documents, whether they are published or not. The documents may come from teaching and research institutions in France or abroad, or from public or private research centers.
L'archive ouverte pluridisciplinaire HAL, est destinée au dépôt et à la diffusion de documents scientifiques de niveau recherche, publiés ou non, émanant des établissements d'enseignement et de recherche français ou étrangers, des laboratoires publics ou privés. 


\section{Environmental determinants of leaf-litter ant community composition along an elevational gradient}

\begin{tabular}{|c|c|}
\hline Journal: & Biotropica \\
\hline Manuscript ID & BITR-19-276.R2 \\
\hline Manuscript Type: & Original Article \\
\hline $\begin{array}{r}\text { Date Submitted by the } \\
\text { Author: }\end{array}$ & 20-May-2020 \\
\hline Complete List of Authors: & $\begin{array}{l}\text { Fichaux, Mélanie; CNRS, UMR Ecologie des Forêts de Guyane (EcoFoG), } \\
\text { AgroParisTech, CIRAD, INRA, Université de Guyane, Université des } \\
\text { Antilles } \\
\text { Vleminckx, Jason; CNRS, UMR Ecologie des Forêts de Guyane (EcoFoG), } \\
\text { AgroParisTech, CIRAD, INRA, Université de Guyane, Université des } \\
\text { Antilles; Florida International University Department of Biological } \\
\text { Sciences, Biological Sciences } \\
\text { Courtois, Elodie; Laboratoire Ecologie, Evolution, Interactions des } \\
\text { Systèmes Amazoniens (LEEISA), Université de Guyane, CNRS, IFREMER; } \\
\text { Centre of Excellence PLECO (Plant and Vegetation Ecology), Department } \\
\text { of Biology, University of Antwerp } \\
\text { Delabie, Jacques; Centro de Pesquisa do Cacau, Laboratório de } \\
\text { Mirmecologia; Universidad Estadual de Santa Cruz, DCAA } \\
\text { Galli, Jordan; CNRS, UMR Ecologie des Forêts de Guyane (EcoFoG), } \\
\text { AgroParisTech, CIRAD, INRA, Université de Guyane, Université des } \\
\text { Antilles; Naturalia Environnement, Site Agroparc, 20 rue Lawrence } \\
\text { Durell, BP 31285 } \\
\text { Tao, Shengli; CNRS, Laboratoire Evolution et Diversité Biologique, } \\
\text { Université Paul Sabatier } \\
\text { Labrière, Nicolas; CNRS, Laboratoire Evolution et Diversité Biologique, } \\
\text { Université Paul Sabatier } \\
\text { Chave, Jérôme; CNRS, Laboratoire Evolution et Diversité Biologique, } \\
\text { Université Paul Sabatier } \\
\text { Baraloto, Christopher; Florida International University Department of } \\
\text { Biological Sciences, Biological Sciences } \\
\text { Orivel, Jerome; CNRS, UMR Ecologie des Forêts de Guyane (EcoFoG), } \\
\text { AgroParisTech, CIRAD, INRA, Université de Guyane, Université des } \\
\text { Antilles }\end{array}$ \\
\hline Keywords: & $\begin{array}{l}\text { ants, climate, elevation, environmental filtering, French Guiana, } \\
\text { functional traits, soil composition }\end{array}$ \\
\hline
\end{tabular}

\section{SCHOLARONE" \\ Manuscripts}


Fichaux et al. Environmental Determinants of Ant Community Composition

1 Environmental determinants of leaf-litter ant community composition along an elevational 2 gradient

3

4 Mélanie Fichaux ${ }^{1 *}$, Jason Vleminckx ${ }^{1,2 *}$, Elodie A. Courtois ${ }^{3,4}$, Jacques H. C Delabie ${ }^{5,6}$, Jordan 5 Galli $^{1,7}$, Shengli Tao ${ }^{8}$, Nicolas Labrière ${ }^{8}$, Jérôme Chave ${ }^{8}$, Christopher Baraloto $^{2}$, Jérôme Orivel ${ }^{1}$

$6{ }^{1}$ CNRS, UMR Ecologie des Forêts de Guyane (EcoFoG), AgroParisTech, CIRAD, INRA,

7 Université de Guyane, Université des Antilles, Campus agronomique, BP 316, 97379, Kourou

8 cedex, France

92 Department of Biological Sciences, Florida International University 11200 S.W. 8th Street 10 Miami, FL 33199, USA

$11{ }^{3}$ Laboratoire Ecologie, Evolution, Interactions des Systèmes Amazoniens (LEEISA), Université

12 de Guyane, CNRS, IFREMER, Cayenne, France

$13{ }^{4}$ Department of Biology, Centre of Excellence PLECO (Plant and Vegetation Ecology), University 14 of Antwerp, Wilrijk, Belgium

$15{ }^{5}$ Laboratório de Mirmecologia, CEPEC, CEPLAC, Caixa Postal 7, Itabuna, BA 45600-970, Brazil

$16{ }^{6}$ Departamento de Ciências Agrárias e Ambientais, Universidade Estadual de Santa Cruz, Rodovia 17 Jorge Amado Km 16, Ilheus, BA 45662-900, Brazil

$18{ }^{7}$ Naturalia Environnement, Site Agroparc, 20 rue Lawrence Durell, BP 31285, 84911 Avignon 19 Cedex 9, France

$20{ }^{8}$ Laboratoire Evolution et Diversité Biologique UMR 5174, CNRS, Université Paul Sabatier, IRD, 21118 route de Narbonne, 31062 Toulouse, France

$22 *$ Co-first authors

23 Corresponding author: Mélanie Fichaux, fichaux.mel@gmail.com 24 
25 Associate Editor: Jennifer Powers

26 Handling Editor: Stephen Yanoviak

27 Received 24 September 2019; revision accepted 1 June 2020.

10

11

12

13

14

15

16

17

18

19

20

21

22

23

24

25

26

27

28

29

30

31

32

33

34

35

36

37

38

39

40

41

42

43

44

45

46

47

48

49

50

51

52

53

54

55

56

57 


\section{Abstract}

30 Ant communities are extremely diverse and provide a wide variety of ecological functions in

31 tropical forests. Here we investigated the abiotic factors driving ant composition turnover across

32 an elevational gradient at Mont Itoupé, French Guiana. Mont Itoupé is an isolated mountain whose

33 top is covered by cloud forests, a biogeographical rarity that is likely to be threatened according to

34 climate change scenarios in the region. We examined the influence of six soil, climatic and LiDAR-

35 derived vegetation structure variables on leaf-litter ant assembly (267 species) across nine 0.12-ha

36 plots disposed at three elevations (ca. 400, 600 and $800 \mathrm{~m}$ asl). We tested (a) whether species co-

37 occurring within a same plot or a same elevation were more similar in terms of taxonomic,

38 functional and phylogenetic composition, than species from different plots/elevations, and (b)

39 which environmental variables significantly explained compositional turnover among plots. We

40 found that the distribution of species and traits of ant communities along the elevational gradient

41 was significantly explained by a turnover of environmental conditions, particularly in soil

42 phosphorus and sand content, canopy height and mean annual relative humidity of soil. Our results

43 shed light on the role exerted by environmental filtering in shaping ant community assembly in

44 tropical forests. Identifying the environmental determinants of ant species distribution along 45 tropical elevational gradients could help predicting the future impacts of global warming on 46 biodiversity organization in vulnerable environments such as cloud forests.

48 Key words: ants; climate; elevation; environmental filtering; French Guiana; functional traits; soil 49 composition. 


\section{1. INTRODUCTION}

52

53 Determining how environmental factors drive biodiversity patterns is one of the fundamental

54 goals in ecology. Predictable changes in diversity and composition of plant and animal

55 communities are observed along broad elevational or latitudinal gradients (Willig et al. 2003,

56 Hillebrand 2004, McCain \& Grytnes 2010). Elevational gradients are particularly valuable to

57 study biodiversity patterns, given that they often span sharp gradients in abiotic conditions even

58 over small spatial scales (e.g. Hodkinson 2005, Kraft et al. 2011, Hoiss et al. 2012). For instance,

59 recurrent patterns observed with increasing elevation involve a continuous decrease of

60 temperature (McCain \& Grytnes 2010), or an increase in soil moisture and organic carbon

61 content (He et al. 2016).

62 Niche models predict that environmental conditions select species with particular traits to

63 establish and persist within an area (Keddy 1992). The effect of environmental filtering may be

64 studied by comparing observed functional or phylogenetic diversity of communities with those

65 expected under nulls models generated by drawing species at random from a regional species

66 pool (e.g. Gotelli 2000). At local to landscape scales, homogeneous environmental conditions

67 should generate assemblages of species that are functionally and phylogenetically (if traits are

68 conserved) more similar than expected by chance (i.e. functional/phylogenetic clustering,

69 respectively). Several studies examining biodiversity patterns along elevational gradients

70 reported a functional or phylogenetic overdispersion of species in lowland assemblages, shifting

71 to a functional or phylogenetic clustering of species in highland assemblages (Graham et al.

72 2009, Machac et al. 2011, Dehling et al. 2014). These results can be interpreted as the effect of

73 increasing strength of environmental filtering on shaping communities (Purschke et al. 2013),

74 which may be caused by the reduction of temperatures with increasing elevation. 
Here we aim to measure the variations in ant community composition and to determine the

76

77

78

79

80

81

82

environmental factors that shape these variations along a Neotropical altitudinal gradient. Ants (Hymenoptera: Formicidae) represent an ideal model for studying the determinants of species

distribution and coexistence because they are abundant and ecologically dominant in terrestrial ecosystems (Hölldobler \& Wilson 1990) and they perform a wide variety of ecological functions such as predation, scavenging and seed dispersal (Folgarait 1998, Del Toro et al. 2012).

Furthermore, previous studies have shown that ant community composition can change markedly along environmental gradients (e.g. Bihn et al. 2010, Yates et al. 2011, Arnan et al. 2014, Groc et al. 2014, Silva \& Brandão 2014, Smith et al. 2014, Bishop et al. 2015, Fontanilla et al. 2019).

Nevertheless, few studies have investigated changes in ant community composition along elevational gradients in tropical regions (Brühl et al. 1999, Dunn et al. 2009, Smith et al. 2014, Nowrouzi et al. 2016). Elevational gradients deserve a special attention because they are characterized by a sharp change of various abiotic conditions, especially temperature and humidity, which are predicted to shape ant species distribution. For instance, Nowrouzi et al. (2016) have emphasized marked species turnovers between 600 and $800 \mathrm{~m}$, which in their study site corresponded to a transition between lowland and cloud forests. Considering the rise of the cloud layers that is predicted by climate change scenarios and associated increases in temperature and decreases in relative humidity (Helmer et al. 2019, Los et al. 2019), it is urgent to characterize species distributions in these environments to assess threats to their persistence. To address this gap, we assess how taxonomic, functional and phylogenetic composition of Neotropical ant assemblages are shaped by different environmental parameters along an elevational gradient. We focused on leaf-litter ants because they are easily sampled with a standardized and generalizable collection protocol and their taxonomy has been well described in the region (Groc et al. 2009, Fichaux et al. 2019). We collected leaf-litter ants at Mont Itoupé 
99 (French Guiana), a mountain which represents a particular biogeographic interest, because of its 100 isolation and its relatively high elevation (ca. 800m) in the eastern Guiana Shield. The top of the 101 mountain is covered by cloud forests, a biogeographic rarity that is likely to be threatened 102 according to scenarios of climate change in this region. Climatic parameters, such as temperature 103 and humidity, may represent major drivers of ant species distributions (e.g. Sanders et al. 2007, 104 Dunn et al. 2009, Silva \& Brandão 2014, Arnan et al. 2015). Variation in habitat characteristics 105 such as nutrient availability, vegetation cover as well as soil texture may also play an important 106 role (Vasconcelos et al. 2003, Chen et al. 2015, Blatrix et al. 2016, Schmidt et al. 2016).

107 We sampled along these gradients to address two main objectives. First, we assessed if ant 108 community structure differed from a random distribution of species along the elevational 109 gradient. A stronger effect of environmental filtering is generally observed at highest elevations, 110 leading to a clustered assemblage structure (Graham et al. 2009, Machac et al. 2011, Dehling et 111 al. 2014, Smith et al. 2014). Thus, we expected to observe clustered patterns among the leaf-litter 112 assemblages at Mont Itoupé, as a result of the effects of the environmental filtering particularly at 113 high altitude. Second, we identified the main environmental determinants (soil, climate and 114 vegetation structure as measured by LiDAR) of the taxonomic, functional and phylogenetic 115 composition of ant assemblages. A decrease in ant diversity along elevational gradients is a 116 common pattern (Brühl et al. 1999, Machac et al. 2011, Longino et al. 2014, Fontanilla et al. 117 2019) which may be explained by the variation in climatic or soil parameters. We therefore 118 expected both climate and soil variables to be strongly correlated with variation in leaf-litter ant 119 assemblages' composition. Moreover, ant species turnover has been shown to be highly 120 coordinated with tree species turnover in the region, independently from environmental gradients 121 (Vleminckx et al. 2019). We may therefore expect a change of ant species composition with 
122 elevation considering previous evidence that forest structure and composition change along 123 elevational gradients (Swenson et al. 2011).

125 2. METHODS

126

127 2.1. Experimental design

128 We collected ants during the dry season in November 2014 , at Mont Itoupé $\left(3^{\circ} 01\right.$ '10.32”N, $12953^{\circ} 04^{\prime} 45.90^{\prime \prime}$ ), French Guiana. Mont Itoupé, located in the heart of the National Park of the 130 Amazon in French Guiana, peaks at an altitude of $830 \mathrm{~m}$ asl, representing one of the highest peaks 131 within $250 \mathrm{~km}$. A total of nine 0.12 -ha plots were established at approximately $400 \mathrm{~m}, 600 \mathrm{~m}$ and $132800 \mathrm{~m}$ asl, with three plots per elevation range, spanning a total area of ca. $10 \mathrm{~km}^{2}$ (Figure 1 ). The 133 plots were chosen to span the range of variation in both climatic and soil conditions across the 134 site. Mean annual rainfall in the area reached $2584 \mathrm{~mm}(<140 \mathrm{~mm}$ of difference across 135 elevations) while mean annual temperature ranged from 23.0 at $400 \mathrm{~m}$ to $21.6^{\circ} \mathrm{C}$ at $800 \mathrm{~m}$ 136 (worldclim.com).

137 Each plot represented an area of $30 \mathrm{~m} \times 40 \mathrm{~m}$, within which we established a grid system of 13820 sampling points separated by at least $10 \mathrm{~m}$, according to the Ants of Leaf Litter Protocol 139 described in Agosti \& Alonso (2000). At each sampling point, we collected leaf-litter ants using 140 pitfall traps and the mini-Winkler method (for more details, see Bestelmeyer et al. 2000). Pitfall 141 traps were left in the ground for 72 hours while the mini-Winkler extractors were installed for 48 142 hours. Because pitfall traps and mini-Winkler extractors were used as complementary traps, we 143 pooled data from both methods in our analyses. Thus, only a single occurrence was reported for a 144 species collected in both traps at the same sampling point. 


\subsection{Ant identification}

147 Ants were identified at the species level whenever possible, or assigned to a morpho-species

148 code. Species identification was mainly based on online identification keys published on Antwiki

149 (http://www.antwiki.org/wiki/Category:Identification_key) and keys developed by John T.

150 Longino (http://ants.biology.utah.edu/AntsofCostaRica.html). We also used the reference

151 collection of the Laboratory Ecofog (Kourou, French Guiana). For the morphospecies with

152 problematic morphological identification (i.e. species from the genera Hypoponera, Nylanderia,

153 Pheidole and Solenopsis), we also sequenced the 16S rRNA barcode (at least three specimens per

154 morphospecies) using the protocol developed by Kocher et al. (2016). DNA sequences were

155 compared to a local reference barcode library for the ant species of French Guiana (under

156 development; unpublished data). Samples are housed in the Laboratory Ecofog, with voucher

157 specimens deposited in the Laboratorio de Mirmecologia, Cocoa Research Centre

158 CEPEC/CEPLAC (Itabuna, BA, Brazil) under the references \#5761 (mini-Winkler traps) and $159 \quad$ \#5762 (pitfall traps).

161 2.3. Morphological data

162 We measured nine morphological attributes (Table 1) using an ocular micrometer accurate to

$1630.01 \mathrm{~mm}$ mounted on a Leica M80 dissecting microscope (Leica Microsystems, Heerbrugg,

164 Switzerland). Traits were selected based on their expected link with ecological strategies related

165 to resource use (Table 1). Measures were performed for all the species collected (i.e. 267

166 species), using at least six randomly selected (minor-caste) workers per species whenever

167 possible (Table S1).

168

169

\subsection{Phylogenetic data}


170 We produced a genus-level phylogenetic tree and calculated phylogenetic distances among all

171 inventoried genera $(n=56)$ using the phylogenetic tree produced in a recent publication

172 (Blanchard \& Moreau 2016). Because two genera sampled in this study (Gigantiops and

173 Rasopone) were missing in the tree of Blanchard \& Moreau (2016), our resulting tree contained 17454 genera (Figure S1).

175

$176 \quad$ 2.5. Environmental data

177 We measured environmental parameters from soil, climatic and LiDAR data.

$178 \quad$ 2.5.1. Soil data

179 In each plot, soil samples were collected at ten locations from three different soil layers $(0-10$,

$18010-20,20-30 \mathrm{~cm})$, following the procedure described in Baraloto et al. (2011). The 10 samples for 181 each depth were then bulked into a single composite sample of ca. $500 \mathrm{~g}$ of soil. Composite

182 sample were then transported to the Laboratory Ecofog and dried to reach constant weight at $18325^{\circ} \mathrm{C}$, sieved to $2 \mathrm{~mm}$ and sent to the INRA Arras soil analysis laboratory (Arras, France) for 184 physical and chemical analyses. A set of nine physico-chemical properties were measured (Table $185 \mathrm{~S} 2)$ : the percentage of sand, silt and clay, soil $\mathrm{pH}$, the percentage of organic matter (OM), the 186 carbon-to-nitrogen ratio $(\mathrm{C} / \mathrm{N})$, and the soil $\mathrm{P}, \mathrm{Na}$ and $\mathrm{K}$ contents. Particle size analysis of sand, 187 silt and clay were quantitatively performed by their settling rates in an aqueous solution using a 188 hydrometer. Soil $\mathrm{pH}$ was measured in $1 \mathrm{M}$ potassium chloride solution. The organic matter 189 content was determined based on the loss of gases after ignition for $2 \mathrm{~h}$ at $360^{\circ} \mathrm{C}$. The total 190 amount of nitrogen (N) and carbon (C) in all forms in soil were quantitatively analyzed using a 191 dynamic flash combustion system coupled with a gas chromatographic separation system and 192 thermal conductivity detection system. Extractable Phosphorus (P) was assayed using the Olsen 193 method (Olsen et al. 1954) based on the extraction of phosphate from the soil by $0.5 \mathrm{~N}$ sodium 
194 bicarbonate solution adjusted to $\mathrm{pH}$ 8.5. A semi-quantitative method was used to determine the 195 amount of soil exchangeable sodium $(\mathrm{Na})$ and potassium $(\mathrm{K})$ residing on the soil colloid 196 exchange sites by displacement with ammonium acetate solution buffered to $\mathrm{pH}$ 7.0.

197

198

\subsubsection{Climatic data}

199 Air temperature (in ${ }^{\circ} \mathrm{C}$ ) and relative humidity (in \%) were measured in all plots using micro200 environmental sensors (HOBO U23-001) as described in Tymen et al. (2017). The weather

201 sensors were placed within the area of each plot except for Plot 6, for which the sensor was 202 placed halfway between Plot 5 and 6 because of a logistical issue. Since this sensor was not far 203 away for the sampled area and at the same elevation, the climatic data were used as a proxy for 204 environmental data of this plot (see Figure 1).

205 The two parameters (air temperature and relative humidity) were monitored for one year, 206 from 1 January 2015 to 31 December 2015 with one measurement every 30 minutes. Using the 207 local micro-environmental data, we defined four climatic variables for each plot (Table S2):

$208 \mathrm{~T}_{\text {MEAN }}$ - mean annual Temperature, $\mathrm{RH}_{\text {MEAN }}$ - mean annual Relative Humidity, $\mathrm{T}_{\mathrm{MIN}}-$ minimum 209 temperature of the coldest month, $\mathrm{RH}_{\mathrm{MIN}}$ - minimum Relative Humidity of the driest month. 210

211 2.5.3. LiDAR data

212 LiDAR data were acquired in early August 2014 using a LMS-Q560 RIEGL laser range finder 213 (wave length $1550 \mathrm{~nm}$ ) on board an aircraft flying at ca. $600 \mathrm{~m}$ above the ground. A total of 64 $214 \mathrm{~km}^{2}$ were covered with a scan angle ranging from $\pm 25^{\circ}$. Point density slightly exceeded 20 $215 \mathrm{pts} / \mathrm{m}^{2}$ (pulse density ca. 13 pulses $/ \mathrm{m}^{2}$ ), with a ground point density of $0.31 \mathrm{pts} / \mathrm{m}^{2}$. Digital 216 Elevation Model (DEM) at $1 \mathrm{~m}$ resolution was interpolated from ground LiDAR points using 217 Lastools (Insenburg n.d.). Digital Surface Model (DSM) was built using Quick Terrain Modeler 
218 (free trial version, http://appliedimagery.com) at the same resolution. Canopy Height Model

219 (CHM) was then calculated as the difference between DSM and DEM. When we ground-

220 surveyed our plots, multiple GPS point positions were acquired for each plot using a hand-held

221 GPS (accuracy 5-10m). To further improve plot geo-referencing, we adjusted plot locations

222 against LiDAR CHM as in Réjou-Méchain et al. (2015): the location of all surveyed trees (DBH

$223 \geq 30 \mathrm{~cm}$ ) inferred from ground positioning was first compared to that deduced from CHM. Tree

224 GPS coordinates were then shifted until best match with the CHM, resulting in horizontal shifts

225 typically of less than $15 \mathrm{~m}$. With the improved plot locations, we then derived three variables for

226 the plots from LiDAR data (Table $\mathrm{S} 2)$ : canopy height $\left(\mathrm{C}_{\mathrm{H}}\right)$, canopy cover $\left(\mathrm{C}_{\mathrm{COV}}\right)$ and the gap

227 fraction (gap). Canopy height was calculated as the mean value of CHM pixels inside each plot.

228 Canopy cover was calculated using LAStools (lascanopy-cov), with the height threshold set at

$2295 \mathrm{~m}$ for separating canopy and non-canopy points. Gap fraction was also calculated following the

230 approach of Morsdorf et al. (2006), which was defined as the percent of vegetation echoes to all

231 (ground and vegetation) echoes.

232

233 2.6. Data analysis

234 All analyses were conducted using R 3.5.1 statistical software (R Core Team 2018). The

235 taxonomic, functional and environmental datasets are available in supplementary material (Tables

$236 \mathrm{~S} 1, \mathrm{~S} 2$ and S3).

237

$238 \quad$ 2.6.1. Functional heterogeneity among species

239 The mean value of traits $(n=9)$ per species were normalized by using a Box-Cox transformation,

240 then all traits (except Weber's length) were standardized by dividing their values by Weber's

241 length to correct for individual body size (see Table 1). A Principal Component Analysis (PCA) 
242 on the species $\times$ traits matrix (hereafter, PCA $_{\text {TRAITS }}$ ) was then performed to eliminate trait

243 redundancy (see Figure S2), using the R package "FactoMineR" (Lê et al. 2008). Subsequent

244 analyses were based on the first three principal components (except for the fourth-corner analysis

245 for which we also used individual traits; see below), which jointly explained 77\% of the overall

246 trait inertia (Table S4).

247

$248 \quad$ 2.6.2. Environmental heterogeneity among plots

249 Environmental variables were normalized (using Box-Cox transformation) and standardized (z-

250 score transformation) prior to analyses, using the R package "forecast" (Hyndman \& Khandakar

251 2008, Hyndman et al. 2019). We then performed a PCA on all environmental variables $(\mathrm{n}=17)$,

252 hereafter the $\mathrm{PCA}_{\mathrm{ENV}}$, to examine associations among variables and characterize environmental

253 differences among plots. The difference among the three elevations for each environmental

254 variable was tested using a Kruskal-Wallis test.

255

256 2.6.3. Community-wide taxonomic, functional and phylogenetic structure

257 A community that is taxonomically, functionally or phylogenetically clustered within plot

258 corresponds to a situation where species co-occurring within these plots share more similar taxa,

259 traits, or are phylogenetically closer-related, respectively, than species from different plots. This

260 clustering was quantified using the $\mathrm{I}_{\mathrm{ST}}, \tau_{\mathrm{ST}}$ and $\Pi_{\mathrm{ST}}$ statistics which calculate the taxonomic,

261 functional and phylogenetic turnover among plots, respectively (Hardy \& Senterre 2007). The

262 three indices are calculated as followed:

$263 \mathrm{I}_{\mathrm{ST}}=1-\mathrm{TD}_{\mathrm{w}} / \mathrm{TD}_{\mathrm{a}}$ (Taxonomic turnover) eq. 1

$264 \tau_{\mathrm{ST}}=1-\mathrm{FD}_{\mathrm{w}} / \mathrm{FD}_{\mathrm{a}}$ (Functional turnover) eq. 2 
266 where TD corresponds to the Taxonomic Diversity calculated using Simpson index with species 267 occurrence data; FD and PD correspond, respectively, to the mean Functional Dissimilarity (here, 268 Euclidean) between distinct species and the mean Phylogenetic Distance (mean divergence time 269 based on the phylogenetic tree) between distinct genera (thus FD and PD are based on 270 species/genus presence-absence), within (w) and among (a) plots. $\tau_{\mathrm{ST}}$ and $\Pi_{\mathrm{ST}}$ thus quantify the 271 relative increase of the mean functional divergence and phylogenetic distance between species 272 sampled among plots versus within plots, respectively. Species, trait and phylogenetic clustering 273 is observed if $\mathrm{I}_{\mathrm{ST}}, \tau_{\mathrm{ST}}$ or $\Pi_{\mathrm{ST}}>0$, respectively, while negative values indicate overdispersion 274 (Hardy \& Senterre 2007). The overall clustering within plot was calculated using the mean $\mathrm{I}_{\mathrm{ST}}$, $275 \tau_{\mathrm{ST}}$ and $\Pi_{\mathrm{ST}}$ values among all pairs of plots. These mean values were tested by comparing their 276 observed value with 999 null values obtained under a null model where species occurrences are 277 randomized across plots (Hardy 2008). We then used the pairwise values of these statistics 278 among all pairs $(n=36)$ of different plots in regression models to test the effect of environmental 279 dissimilarity on taxonomic, functional and phylogenetic turnover (see next section). Turnover 280 values were also quantified and tested among pairs of altitudes (three comparisons, 400-600m, $281400-800 \mathrm{~m}$ and 600-800m). These indices were calculated using the R package "spacodiR"

282 (Eastman et al. 2013).

284 2.6.4. Environmental determinants of taxonomic, functional and phylogenetic composition

285 We used Multiple Regression on distance Matrices (MRM; Lichstein 2007) to quantify and test 286 the association between environmental dissimilarity and taxonomic $\left(\mathrm{I}_{\mathrm{ST}}\right)$, phylogenetic $\left(\Pi_{\mathrm{ST}}\right)$ and 287 functional $\left(\tau_{\mathrm{ST}}\right)$ turnover of ant assemblages among plots, using the R package "ecodist" (Goslee 
288 \& Urban 2007). Statistical significance of each regression coefficient was assessed through 289 residuals permutation tests $\left(\mathrm{n}=9,999\right.$ permutations). Pairwise $\tau_{\mathrm{ST}}$ values corresponded more 290 exactly to the functional turnover among plots calculated using the three first axes of the 291 PCA $_{\text {TRAITS }}$ together, as well as each of these axes individually. Analyzing the functional turnover 292 based on individual PCA axes can help identifying significant effects on traits that may be 293 obscured when all traits are taken into account in the analysis. The examination of trait loadings 294 on the PCA axes can help identifying those traits (Figure 2). It is worth noting that all of our tests 295 may suffer from a limited statistical power due to the number of pairwise turnover values $(\mathrm{n}=36)$ 296 investigated in the MRM. Thus, while the significant signals observed may reflect some 297 ecological reality, the absence of signals should also be taken with caution as they could mean 298 that our sampling design did not allow capturing a significant association.

299 Three types of MRM models were used for each of the six response variable $\left(\mathrm{I}_{\mathrm{ST}}, \tau_{\mathrm{ST}}\right.$ 300 calculated over the three first axes of the PCA $A_{\text {TRAITS }}, \tau_{\mathrm{ST}}$ calculated for each of these three axes, 301 and $\Pi_{\mathrm{ST}}$ ). The first model (Model 1) corresponded to a simple regression testing the effect of the 302 overall environmental (Euclidean) dissimilarity (calculated over the 17 environmental variables) 303 on each response variable. Model 2 corresponded to a multiple regression model where we tested 304 the relative effects (regression coefficients) of the dissimilarity of several environmental 305 variables, using a reduced set of variables with limited collinearity to limit the number of tests. 306 To do so, we retained ecologically relevant variables with $r$-Spearman correlation $\leq 0.6$ for 307 climate and soil variables separately (Figures S3-4). In doing so, four soil variables (the 308 percentage of sand, $\mathrm{OM}$, soil $\mathrm{pH}$ and $\mathrm{P})$ and one climatic variable $\left(\mathrm{RH}_{\mathrm{MEAN}}\right)$ were retained for 309 analyses. For LiDAR data, because the variation in the variables "canopy cover" and "gap 310 fraction" remained virtually unchanged across plots (see Table S2), we only retained the variable 311 "canopy height" $\left(\mathrm{C}_{\mathrm{H}}\right)$ for analyses. This latter variable was positively correlated to the variables 
312 "canopy cover" and "gap fraction" (Figure S5). In Model 3, we tested the relative effects of the 313 dissimilarity in the scores of the two first axes of the $\mathrm{PCA}_{\mathrm{ENV}}$. In each of the three models, the 314 spatial dependence among plots was taken into account by including spatial distance (Euclidean, 315 untransformed) among the explanatory variables.

316 Finally, to have more accurate insights regarding the associated pairs of environmental 317 variables and traits, we performed a fourth-corner analysis (Legendre et al. 1997), using the R 318 packages “ade4" (Dray \& Dufour 2007) and "adespatial” (Dray et al. 2019). The fourth-corner 319 analysis combines three matrices - plots $\times$ environmental variables $(\mathrm{R})$, plots $\times$ species 320 occurrences (L) and species $\times$ traits (Q) - into a matrix of trait-environment associations. The 321 latter is then used to quantify and test pairwise associations between traits and environmental 322 variables, using 9,999 randomizations with the so-called model " 6 " which combines models " 2 " 323 and "4" as described in Dray et al. (2014), in order to avoid type-I error inflation.

\section{RESULTS}

We collected a total of 31,865 ant individuals belonging to 267 species, 56 genera and 11 subfamilies along the elevational gradient at Mont Itoupé (Table S3). The total number of species slightly decreased with increasing elevation (resp. 198, 176 and 161 species at 400m, 600m and $330800 \mathrm{~m}$ asl.). Across plots, the number of observed species ranged from 85 (P6; 600m asl.) to 129 331 (P9; 400m asl.). The average number of species per sample was higher at the lowest elevations 332 (400m: mean $\pm \mathrm{sd}=25.45 \pm 2.69 ; 600 \mathrm{~m}:$ mean $\pm \mathrm{sd}=20.38 \pm 4.48 ; 800 \mathrm{~m}:$ mean $\pm \mathrm{sd}=20.63 \pm$ 333 1.60). We also calculated the Simpson's index and found very similar values along the 334 elevational gradient (mean $\pm \mathrm{sd}=0.98 \pm<0.01$ for each elevation). 


\subsection{Functional heterogeneity}

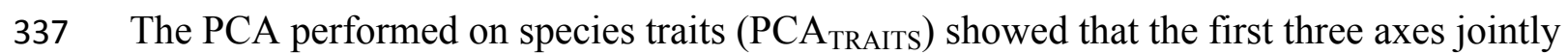

338 explained $77 \%$ of the overall trait inertia $(38 \%, 26 \%$ and $13 \%$, respectively; Figures 2 and S6;

339 Table S4). Plot scores on the first axis were highly positively correlated to HL, HW, PW and

340 negatively to WL. The second axis was mostly associated with FL, SL and EL which were highly

341 positively correlated to each other; the third axis was negatively associated to ML (Figures 2 and

342 S6, Table S4).

343

\subsection{Environmental heterogeneity}

345 The PCA performed on the matrix of environmental data (hereafter, $\mathrm{PCA}_{\mathrm{ENV}}$ ) revealed that axes

3461 and 2 explained $60.5 \%$ and $20.7 \%$ of the overall environmental inertia across the nine plots,

347 respectively (Figure 3; Table S5). Among the variables retained for analyses, PCA scores

348 indicated that relative humidity $\left(\mathrm{RH}_{\mathrm{MEAN}}\right)$ and canopy height $\left(\mathrm{C}_{\mathrm{H}}\right)$ were strongly correlated to

349 axis 1 (resp. $\mathrm{r}=0.93$ and $\mathrm{r}=-0.90)$, while $\mathrm{pH}$ was strongly correlated to axis $2(\mathrm{r}=0.85)$.

350 We found that the following variables significantly (or almost) varied across elevations (Kruskal-

351 Wallis rank tests): $\mathrm{OM}\left(X^{2}=7.20, \mathrm{p}=0.03\right), \mathrm{C}_{\mathrm{H}}\left(X^{2}=6.00, \mathrm{p}=0.05\right), \mathrm{P}\left(X^{2}=2.40, \mathrm{p}=0.06\right)$

352 and $\mathrm{RH}_{\text {MEAN }}\left(X^{2}=5.42, \mathrm{p}=0.07\right)$. In contrast, no significant variation was found in sand $\left(X^{2}=\right.$

$3532.40, \mathrm{p}=0.30)$ and soil $\mathrm{pH}\left(X^{2}=0.61, \mathrm{p}=0.74\right)$ across elevations.

\section{3.3. Taxonomic, functional and phylogenetic structure of ant assemblages}

356 The leaf-litter ant assemblages displayed significant taxonomic and trait clustering at the plot

357 level (Table 2). Trait clustering was mostly explained by a significant clustering observed for the

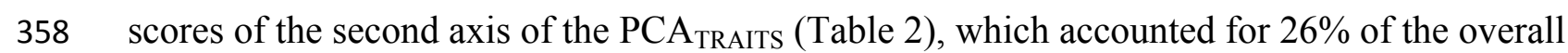

359 functional inertia. The latter axis (i.e. axis 2 of the PCA $\mathrm{A}_{\text {TRAITS }}$ ) was mostly associated to relative 
360 femur and scape length (Figure 2; Table S4). In contrast, we did not find any significant

361 phylogenetic clustering (Table 2). We further found that the taxonomic clustering was mostly due

362 to differences in species composition between 800 and $600 \mathrm{~m}$-elevated plots, and that the

363 functional clustering was mostly due to differences in trait composition between the most

364 elevated plots $(800 \mathrm{~m})$ and the other plots (Table 2). No phylogenetic clustering signal was found

365 at the plot or the elevation level.

3.4. Effect of environmental variables on taxonomic, functional and phylogenetic

\section{composition}

369 To facilitate the reading hereafter, we will sometimes omit to use the term "dissimilarity" when

370 describing that the "dissimilarity of A significantly explains the dissimilarity of B", and will

371 simply write that "A significantly explains B" but we must keep in mind that we only deal with

372 dissimilarity values among plots in our regression models. The overall environmental

373 dissimilarity significantly explained the taxonomic $\left(\mathrm{I}_{\mathrm{ST}}\right)$ and the overall functional $\left(\tau_{\mathrm{ST}}\right)$ turnover

374 among plots (Table 3) but not the phylogenetic $\left(\Pi_{\mathrm{ST}}\right)$ turnover. Moreover, the scores of the first

375 axis (strongly associated to the Weber's length, the relative head length, the relative head width

376 and the pronotum width) and second axis (strongly associated to the relative scape and the

377 relative femur lengths) of the PCA $_{\text {TRAITS }}$ were significantly explained by the overall

378 environmental dissimilarity.

379 Meanwhile, the plot scores of the first axis of the PCA $\mathrm{ENV}_{\text {(which was strongly associated }}$ 380 with temperature, relative humidity and vegetation structure; Table S5) significantly explained 381 the variation in the overall taxonomic and functional composition, as well as the variation in the

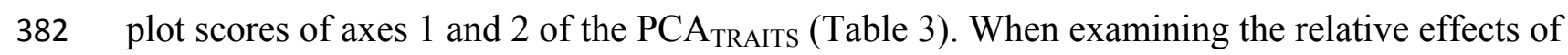
383 each of the six selected environmental variable (sand, $\mathrm{pH}, \mathrm{OM}, \mathrm{P}, \mathrm{RH}_{\mathrm{MEAN}}$ and $\mathrm{C}_{\mathrm{H}}$ ), we found 
384 that soil phosphorus content and canopy height significantly explained the taxonomic 385 composition $\left(\mathrm{I}_{\mathrm{ST}}\right)$ but not the overall functional composition $\left(\tau_{\mathrm{ST}}\right)$, the latter being only explained 386 by the percentage of sand (with a marginal significance; $p=0.081$ ). Although the second axis of 387 the PCA $\mathrm{A}_{\text {TRAITS }}$ displayed the strongest association with environment and with the first axis of the $388 \mathrm{PCA}_{\mathrm{ENV}}$, it was not significantly explained by any individual environmental variable, despite a 389 relatively high coefficient value obtained with $\mathrm{C}_{\mathrm{H}}$, which may result from a lack of power. Axis 1 390 and 3 of the PCA $\mathrm{A}_{\text {TRAITS }}$, however, were both significantly explained by soil phosphorus, while 391 axis 1 was also significantly explained by $\mathrm{pH}$ and axis 3 by the percentage of sand. The 392 phylogenetic $\left(\Pi_{\mathrm{ST}}\right)$ turnover was (marginally) significantly explained by soil $\mathrm{pH}$ only.

393 The fourth-corner analysis indicated that the percentage of sand was negatively related to 394 the relative scape, eye and femur lengths, and to the second and third axes of the PCA $\mathrm{ARAITS}_{\mathrm{T}}$ 395 (Table 4) which were highly associated to the variation of these three traits, while the third axis 396 was also strongly correlated to the relative mandible length (Table S4). Phosphorus concentration 397 was positively related to relative head length, whereas it was negatively related to Weber's length

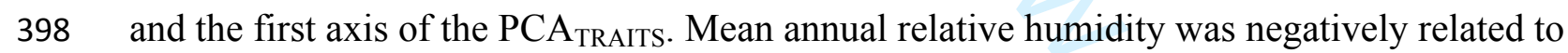
399 relative scape, eye and femur lengths of ants (Table 4).

400

\section{DISCUSSION}

402

403 This study highlights the existence of associations between key abiotic environmental variables 404 and the distribution of species and functional traits among Neotropical ant assemblages at a local 405 (i.e. $10 \mathrm{~km}^{2}$ ) scale. Ant species and functional composition were mostly explained by canopy 406 height and the first axis of the $\mathrm{PCA}_{\mathrm{ENV}}$ which was strongly associated to the relative humidity 407 and temperature (and thus elevation), and to a lesser extent by soil phosphorus concentration, 
408 sand and $\mathrm{pH}$ (Table 3). The observed within-plot and within-elevation functional clustering

409 (Table 2) likely arose from the filtering of these environmental conditions.

410 Climate represents a major environmental filter and restricts the number and identity of

411 species that can survive and establish at different locations. Among climatic filters, temperature

412 has been shown to be a key parameter influencing patterns of ant species distributions (e.g.

413 Sanders et al. 2007, Dunn et al. 2009, Silva \& Brandão 2014). Other studies have also reported a

414 relationship between temperature and ant functional composition (Stuble et al. 2013, Arnan et al.

415 2014). Relative humidity may be even more constraining for leaf-litter ants than temperature

416 (Kaspari \& Weiser 2000, Menke \& Holway 2006). These studies reported results that were

417 consistent with our findings. Indeed, we found that the variation in the dissimilarity of plot scores

418 along the first axis of the PCA $\mathrm{ENV}_{\mathrm{EN}}$, which was highly explained by variation in soil relative

419 humidity, temperature and elevation (Figure 3; Table S5), significantly explained the taxonomic

420 and functional turnover. As highlighted by the PCA generated on environmental data $\left(\mathrm{PCA}_{\mathrm{ENV}}\right.$;

421 Figure 3), the top of the mountain (ca. 800m asl), which is covered by cloud forests, is

422 characterized by slightly higher levels of humidity ( mean $\left._{\mathrm{RH}}=99.3 \%\right)$ compared to lower

423 elevations (between ca. 400 and $600 \mathrm{~m}$ asl; $\operatorname{mean}_{\mathrm{RH}}=96.5 \%$ ). The top forests may therefore

424 provide a refuge area for certain species preferring relatively colder and more humid conditions.

425 Changes in species and functional composition may thus reflect the presence of climate-

426 specialists at higher elevations. More specifically, our results suggest that smaller ant species, as

427 well as species with relative smaller eyes or smaller legs, were found in sites with higher levels of

428 humidity (thus at higher elevation). These traits are characteristics of hypogaeic ant species, i.e.

429 ant species that nest and forage within the litter or into the soil (Weiser \& Kaspari 2006).

430 Along Mont Itoupé, turnovers in species and functional composition were also associated to 431 variation in phosphorus concentration (Table 3). Phosphorus limitation may explain variation in 
432 plant diversity (Wright et al. 2011, Vleminckx et al. 2017), which in turn is likely to influence the 433 diversity and density of leaf-litter associated invertebrates (McGlynn \& Salinas 2007, Vleminckx 434 et al. 2019). In their study, McGlynn and Salinas (2007) found that environments richer in 435 phosphorus had greater litter invertebrate densities (mostly detritivores). Thus, the association 436 between phosphorus availability and the species and functional composition of ant communities 437 may be indirectly explained by the variation in the density of prey for predatory ant species. The 438 fourth-corner analysis performed in this study reveal that phosphorus concentration was 439 positively related to the relative head length and negatively related to body length (i.e. Weber's 440 length), features that are characteristics of small hypogaeic ant species belonging to genera such 441 as Carebara, Solenopsis and Strumigenys. Those predatory ant genera may thus benefit from the 442 higher phosphorus concentrations that may favor the abundance of small prey. Such results 443 contrast with those obtained in a study conducted by Jacquemin et al. (2012) in which they found 444 a decrease of predatory ant species in plots enriched in Carbon, Nitrogen and Phosphorus. In their 445 study, predatory ants seemed to be limited by habitat loss due to the increased litter 446 decomposition. The positive effect of higher levels of phosphorus for small predatory ant species 447 found in our study may have been counterbalanced by habitat loss in their study, since the 448 amount of leaf litter at the highest elevation, i.e. at high levels of phosphorus, was much more 449 important than at the lowest ones.

450 In addition to climatic factors, nutrient availability and soil texture can also influence 451 invertebrate composition by imposing constraints on species living in ground habitats 452 (Vasconcelos et al. 2003, Schmidt et al. 2016, Costa-Milanez et al. 2017), but also indirectly via 453 an effect of these variables on tree community assembly (Vleminckx et al. 2019). In our study, a 454 significant association was found between the functional composition and the soil texture 455 (percentage of sand) turnover across plots (Table 3), especially for the third axis of the PCA $\mathrm{A}_{\text {TRAITS }}$ 
456 which was mostly associated with the relative mandible length (Table S4). We lack hypotheses to

457 explain that result. In addition, the percentage of sand was negatively related to individual

458 functional traits of ants (i.e. the relative scape and femur lengths). Particular functional traits of

459 ant species rather than the global functional space of ant assemblages may thus be linked to soil

460 texture. Short scape and eye, relative to body size, are typical of hypogaeic ant species (Brandão

461 et al. 2012), foraging and nesting inside the leaf-litter. Sandy soils may thus favor movements

462 and nest establishment of hypogaeic species within the litter, compared to clay-rich soils.

463

464 CONCLUSIONS

465

466 Elevational gradients stretching from lowland forests to lower mountain cloud forests represent a

467 major source of environmental variation in tropical regions which, in our study, has been shown

468 to influence the distribution of leaf-litter ants. In particular, the taxonomic and functional

469 turnover of ant communities were mostly explained by soil phosphorus content, climatic

470 (temperature, relative humidity) variables and vegetation structure, while trait variation seemed to

471 be also influenced by soil texture and $\mathrm{pH}$. Our results shed light on the unique biodiversity value

472 of cloud forests, a particularly rare ecosystem in the eastern Guiana Shield, likely to be threatened

473 by climate change, with scenarios predicting an intensification of drought events and an increase

474 of temperature across the region (Esquivel-Muelbert et al. 2019). Indeed, the congruence between

475 species and functional turnover along the humidity gradient highlights that a loss of species and

476 functional diversity represent real threats in this regional biodiversity hotspot.

477

478 ACKNOWLEDGMENTS

479 
480 We thank Sandrine Etienne for her work on the process of molecular data, and Aurélie Dourdain 481 for producing the map of the site. Thanks are also due to the national park managers for allowing 482 our research program in the core area of the Parc Amazonien de Guyane. Financial support for this 483 study was provided by an Investissement d'Avenir grant of the Agence Nationale de la Recherche 484 (CEBA, ANR-10-LABX-25-01) through a PhD fellowship to MF and the funding of the 485 DIADEMA (DIssecting Amazonian Diversity by Enhancing a Multiple taxonomic-groups 486 Approach) and DIAMOND (DIssecting And MONitoring amazonian Diversity) projects, by the 487 Programme Convergence 2007-2013, Région Guyane from the European community (BREGA, $488757 / 2014 / \mathrm{SGAR} / \mathrm{DE} / \mathrm{BSF}$ ) and by the PO-FEDER 2014-2020, Région Guyane (BiNG, 489 GY0007194).

490

491 DATA AVAILABILITY

492 Data available from the Dryad Digital Repository: https://doi.org/10.5061/dryad.00000 (Fichaux 493 et al. 2020).

REFERENCES

498

499 Agosti, D., and L. Alonso. 2000. The ALL Protocol. In D. Agosti, J. Majer, L. Alonso, and T. 500 Schultz (Eds.) Ants: standard methods for measuring and monitoring biodiversity. pp. 204-206, 501 Washington D.C. USA.

502 Arnan, X., X. Cerdá, and J. Retana. 2014. Ant functional responses along environmental 503 gradients. Journal of Animal Ecology 83: 1398-1408. 
504 Arnan, X., X. CerdÁ, and J. Retana. 2015. Partitioning the impact of environment and spatial 505 structure on alpha and beta components of taxonomic, functional, and phylogenetic diversity in 506 European ants. PeerJ 3: e1241.

507 Baraloto, C., S. Rabaud, Q. Molto, L. Blanc, C. Fortunel, B. Hérault, N. Dávila, I. 508 Mesones, M. Rios, E. Valderrama, and P. V. A. Fine. 2011. Disentangling stand and 509 environmental correlates of aboveground biomass in Amazonian forests. Global Change Biology $510 \quad 17: 2677-2688$.

511 Bestelmeyer, B. T., D. Agosti, L. E. Alonso, C. R. F. Brandão, W. L. Brown JR., J. H. C. 512 Delabie, and R. Silvestre. 2000. Field techniques for the study of ground-dwelling ants: an 513 overview, description, and evaluation. In D. Agosti, J. Majer, L. Alonso, and T. Schultz (Eds.) 514 Ants: standard methods for measuring and monitoring biodiversity. pp. 122-144, Washington D.C. 515 USA.

516 Bihn, J. H., G. GEBAUER, and R. BRANDL. 2010. Loss of functional diversity of ant assemblages in 517 secondary tropical forests. Ecology 91: 782-792.

518 Bishop, T. R., M. P. Robertson, B. J. van RensburG, and C. L. PARR. 2015. Contrasting species 519 and functional beta diversity in montane ant assemblages. Journal of Biogeography 42: 1776-1786.

520 Blanchard, B. D., and C. S. Moreau. 2016. Defensive traits exhibit an evolutionary trade-off 521 and drive diversification in ants. Evolution 71: 315-328.

522 Blatrix, R., C. Lebas, C. Galkowski, P. Wegnez, R. Pimenta, and D. Morichon. 2016. 523 Vegetation cover and elevation drive diversity and composition of ant communities (Hymenoptera: 524 Formicidae) in a Mediterranean ecosystem. Myrmecological News 22: 119-127.

525 Brandẽo, C. R. F., R. R. Silva, and J. H. C. Delabie. 2012. Neotropical ants (Hymenoptera) 526 functional groups: nutritional and applied implications. In J. R. P. Parra (Ed.) Insect bioecology 527 and nutrition for integrated pest management. pp. 213-236, CRC, Boca Raton. 
528 BrÜHL, C. A., M. Mohamed, and K. E. LinsenMaIR. 1999. Altitudinal distribution of leaf litter 529 ants along a transect in primary forests on Mount Kinabalu, Sabah, Malaysia. Journal of Tropical 530 Ecology 15: 265-277.

531 Chen, X., B. AdAms, C. Bergeron, A. SABo, and L. Hooper-BÙI. 2015. Ant community structure 532 and response to disturbances on coastal dunes of Gulf of Mexico. Journal of Insect Conservation 533 19: $1-13$.

534 Costa-Milanez, C. B. DA, J. D. Majer, P. DE T. A. CAStro, and S. P. Ribeiro. 2017. Influence of 535 soil granulometry on average body size in soil ant assemblages: implications for bioindication. 536 Perspectives in Ecology and Conservation 15: 102-108.

537 DAVIDSON, D. W., S. C. COOK, and R. R. SNELLING. 2004. Liquid-feeding performances of ants 538 (Formicidae): ecological and evolutionary implications. Oecologia 139: 255-266.

539 Dehling, D. M., S. A. Fritz, T. TöPfer, M. Päckert, P. Estler, K. BöHning-Gaese, and M. 540 SCHLEUNING. 2014. Functional and phylogenetic diversity and assemblage structure of frugivorous 541 birds along an elevational gradient in the tropical Andes. Ecography 37: 1047-1055.

542 Del Toro, I., R. R. RibBons, and S. L. Pelini. 2012. The little things that run the world revisited: 543 a review of ant-mediated ecosystem services and disservices (Hymenoptera: Formicidae). 544 Myrmecological News 17: 133-146.

545 Dray, S., and A.-B. Dufour. 2007. The ade4 package: implementing the duality diagram for 546 ecologists. Journal of Statistical Software 22: 1-20.

547 Dray, S., P. Choler, S. Dolédec, P. R. Peres-Neto, W. Thuiller, S. Pavoine, and C. J. F. Ter 548 BRAAK. 2014. Combining the fourth-corner and the RLQ methods for assessing trait responses to 549 environmental variation. Ecology 95: 14-21.

550 Dray, S., D. Bauman, G. Blanchet, D. Borcard, S. Clappe, G. Guenard, T. Jombart, G. 551 LAROCQUE, P. LEGENDRE, N. MADI, and H. H. WAGNER. 2019. adespatial: multivariate multiscale 
552 spatial analysis. R package version 0.3-4, https://CRAN.R-project.org/package=adespatial.

553 DunN, R. R. ET AL. 2009. Climatic drivers of hemispheric asymmetry in global patterns of ant 554 species richness. Ecology Letters 12: 324-333.

555 Eastman, J., T. Paine, and O. Hardy. 2013. spacodiR: spatial and phylogenetic analysis of 556 community diversity. $\mathrm{R}$ package version $0.13-0115$, https://CRAN.R557 project.org/package=spacodiR.

558 Esquivel-Muelbert, A. ET AL. 2019. Compositional response of Amazon forests to climate 559 change. Global Change Biology 25: 39-56.

560 Feener JR., D. H., J. R. B. Lighton, and G. A. BArtholomew. 1988. Curvilinear allometry, 561 energetics and foraging ecology: a comparison of leaf-cutting ants and army ants. Functional 562 Ecology 2: 509-520.

563 Fichaux, M., B. Béchade, J. Donald, A. Weyna, J. H. C. Delabie, J. Murienne, C. Baraloto, 564 and J. ORIVEL. 2019. Habitats shape taxonomic and functional composition of Neotropical ant 565 assemblages. Oecologia 189: 201-513.

566 Fichaux, M., J. VleminckX, E. A. Courtois, J. H. C Delabie, J. Galli, S. TaO, N. Labrière, J. 567 Chave, C. Baraloto, J. Orivel. 2020. Data from: Environmental determinants of leaf-litter ant 568 community composition along an elevational gradient. Dryad Digital Repository.

569 doi:10.5061/dryad.00000

570 Folgarait, P. J. 1998. Ant biodiversity and its relationship to ecosystem functioning: a review.

571 Biodiversity and Conservation 7: 1221-1244.

572 Fontanilla, A. M., A. Nakamura, Z. Xu, M. CaO, R. L. Kitching, Y. TAng, and C. J. Burwell. 573 2019. Taxonomic and functional ant diversity along tropical, subtropical, and subalpine elevational 574 transects in Southwest China. Insects 128. 
575 Fowler, H. G., L. C. Forti, C. R. F. Brandẽo, J. H. C. Delabie, and H. L. Vasconcelos. 1991.

576 Ecologia nutricional de formigas. In A. R. Panizzi and J. R. P. Parra (Eds.) Ecologia nutricional de 577 insetos e suas implicaçoes no manejo de pragas. pp. 131-223, São Paulo, Brazil: Editora Manole.

578 GosleE, S. C., and D. L. URBAN. 2007. The ecodist package for dissimilarity-based analysis of 579 ecological data. Journal of Statistical Software 22: 1-19.

580 Gotelli, N. J. 2000. Null model analysis of species co-occurrence patterns. Ecology 81: 26065812621.

582 Graham, C. H., J. L. Parra, C. RahbeK, and J. A. McGuire. 2009. Phylogenetic structure in 583 tropical hummingbird communities. Proceedings of the National Academy of Sciences 106: $584 \quad 19673-19678$.

585 Groc, S., J. Orivel, A. Dejean, J.-M. Martin, M.-P. Etienne, B. Corbara, and J. H. C. Delabie. 586 2009. Baseline study of the leaf-litter ant fauna in a French Guianese forest. Insect Conservation 587 and Diversity 2: 183-193.

588 Groc, S., J. H. C. Delabie, F. Fernández, M. Leponce, J. Orivel, R. Silvestre, H. L. 589 VAsCONCElos, and A. DEJEAN. 2014. Leaf-litter ant communities (Hymenoptera: Formicidae) in 590 a pristine Guianese rain-forest: Stable functional structure versus high species turnover. 591 Myrmecological News 19: 43-51.

592 Gronenberg, W., J. Tautz, and B. Hölldobler. 1993. Fast trap jaws and giant neurons in the 593 ant Odontomachus. Science 262: 561-563.

594 HARDY, O. J. 2008. Testing the spatial phylogenetic structure of local communities: Statistical 595 performances of different null models and test statistics on a locally neutral community. Journal of 596 Ecology 96: 914-926.

597 HARDY, O. J., and B. SENTERRE. 2007. Characterizing the phylogenetic structure of communities 598 by an additive partitioning of phylogenetic diversity. Journal of Ecology 95: 493-506. 
599 He, X., E. Hou, Y. LiU, and D. Wen. 2016. Altitudinal patterns and controls of plant and soil 600 nutrient concentrations and stoichiometry in subtropical China. Scientific Reports 6: 24261.

601 Helmer, E. H., E. A. Gerson, L. S. BAggett, B. J. Bird, T. S. Ruzycki, and S. M. Voggesser. 602 2019. Neotropical cloud forests and páramo to contract and dry from declines in cloud immersion 603 and frost S. Lötters (Ed.). PLoS ONE 14: e0213155.

604 Hillebrand, H. 2004. On the generality of the latitudinal diversity gradient. The American 605 Naturalist 163: 192-211.

606 HodKInSON, I. D. 2005. Terrestrial insects along elevation gradients: species and community 607 responses to altitude. Biological Reviews 80: 489-513.

608 Hoiss, B., J. Krauss, S. G. Potts, S. Roberts, and I. StefFAn-Dewenter. 2012. Altitude acts as 609 an environmental filter on phylogenetic composition, traits and diversity in bee communities. 610 Proceedings of the Royal Society B: Biological Sciences 279: 4447-4456.

611 Hölldobler, B., and E. O. Wilson. 1990. The Ants. Harvard University Press.

612 Hyndman, R. J., and Y. KHANDAKAR. 2008. Automatic time series forecasting: the forecast 613 package for R. Journal of Statistical Software 27: 1-23.

614 Hyndman, R., G. Athanasopoulos, C. Bergmeir, G. Caceres, L. ChHay, M. O’Hara-Wild, 615 F. Petropoulos, S. RazBAsh, E. WANG, and F. YASMEEN. 2019. forecast: forecasting functions 616 for time series and linear models. $\mathrm{R}$ package version 8.7, <URL: 617 http://pkg.robjhyndman.com/forecast>.

618 InSENBURG, M. LAStools-efficient LiDAR processing software (version 160921, academic) 619 obtained from http://rapidlasso.com/LAStools.

620 Jacquemin, J., M. Maraun, Y. Roisin, and M. LePOnCE. 2012. Differential response of ants to 621 nutrient addition in a tropical Brown Food Web. Soil Biology and Biochemistry 46: 10-17.

622 KASPARI, M. 1993. Body size and microclimate use in Neotropical granivorous ants. Oecologia 96: 
$623500-507$.

624 KASPARI, M., and M. D. WEISER. 1999. The size-grain hypothesis and interspecific scaling in ants. 625 Functional Ecology 13: 530-538.

626 KASPARI, M., and M. D. WeISER. 2000. Ant activity along moisture gradients in a Neotropical 627 forest. Biotropica 32: 703-711.

628 KEDDY, P. A. 1992. Assembly and response rules: two goals for predictive community ecology. 629 Journal of Vegetation Science 3: 157-164.

630 Kocher, A., J.-C. Gantier, P. Gaborit, L. Zinger, H. Holota, S. Valiere, I. Dusfour, R. 631 GiRoD, A. L. BAÑUls, and J. MuRIENNE. 2016. Vector soup: high-throughput identification of 632 Neotropical phlebotomine sand flies using metabarcoding. Molecular Ecology Resources 17: 172633182.

634 Kraft, N. J. B., L. S. Comita, J. M. Chase, N. J. Sanders, N. G. Swenson, T. O. Crist, J. C. 635 Stegen, M. Vellend, B. Boyle, M. J. Anderson, H. V. Cornell, K. F. Davies, A. L. 636 Freestone, B. D. Inouye, S. P. Harrison, and Myers. 2011. Disentangling the drivers of $\beta$ 637 diversity along latitudinal and elevational gradients. Science 1755-1758.

638 LÊ, S., J. JosSE, and F. HuSSON. 2008. FactoMineR: an R package for multivariate analysis. Journal 639 of Statistical Software 25: 1-18.

640 Legendre, P., R. Galzin, and M. L. Harmelin-Vivien. 1997. Relating behavior to habitat: 641 solutions to the fourth-corner problem. Ecology 78: 547-562.

642 LiCHSTEIN, J. W. 2007. Multiple regression on distance matrices: a multivariate spatial analysis 643 tool. Plant Ecology 188: 117-131.

644 Longino, J. T., M. G. Branstetter, and R. K. COLWELl. 2014. How ants drop out: ant abundance 645 on tropical mountains. PloS one 9: e104030.

646 Los, S. O., F. A. Street-Perrott, N. J. Loader, C. A. Froyd, A. Cuní-Sanchez, and R. A. 
647 MARCHANT. 2019. Sensitivity of a tropical montane cloud forest to climate change, present, past 648 and future: Mt. Marsabit, N. Kenya. Quaternary Science Reviews 218: 34-48.

649 Machac, A., M. Janda, R. R. Dunn, and N. J. SAnders. 2011. Elevational gradients in 650 phylogenetic structure of ant communities reveal the interplay of biotic and abiotic constraints on 651 diversity. Ecography 34: 364-371.

652 McCAIn, C. M., and J.-A. GRYTNES. 2010. Elevational gradients in species richness. In 653 Encyclopedia of Life Sciences (ELS). pp. 1-10, John Wiley \& Sons, Ltd, Chichester, UK.

654 McGlynN, T. P., and D. J. SAlinas. 2007. Phosphorus limits tropical rain forest litter fauna. 655 Biotropica 39: 50-53.

656 MenKe, S. B., and D. A. Holway. 2006. Abiotic factors control invasion by Argentine ants at the 657 community scale. Journal of Animal Ecology 75: 368-376.

658 Morsdorf, F., B. Kötz, E. Meier, K. I. ItTen, and B. Allgöwer. 2006. Estimation of LAI and 659 fractional cover from small footprint airborne laser scanning data based on gap fraction. Remote 660 Sensing of Environment 104: 50-61.

661 Nowrouzi, S., A. A. Andersen, S. Macfadyen, K. M. Staunton, J. VanderWal, and S. K. A. 662 RobSOn. 2016. Ant diversity and distribution along elevational gradients in the Australian wet 663 tropics: the importance of seasonal moisture stability. PloS ONE 11: e0153420.

664 Olsen S., C. Cole, F. Watanabe, and L. Dean. 1954. Estimation of available phosphorus in soils 665 by extraction with sodium bicarbonate. USDA Circular $\mathrm{Nr}$ 939, US Gov. Print. Office, 666 Washington, D.C.

667 Purschke, O., B. C. Schmid, M. T. Sykes, P. Poschlod, S. G. Michalski, W. Durka, I. Kühn, 668 M. Winter, and H. C. PRENTICE. 2013. Contrasting changes in taxonomic, phylogenetic and 669 functional diversity during a long-term succession: insights into assembly processes. Journal of 670 Ecology 101: 857-866. 
671 R Core Team. 2018. R: A Language and Environment for Statistical Computing.

672 RÉJou-Méchain, M., B. Tymen, L. Blanc, S. FAuset, T. R. FeldPausch, A. Monteagudo, O.

673 L. PHILliPS, H. RichARD, and J. CHAVE. 2015. Using repeated small-footprint LiDAR acquisitions

674 to infer spatial and temporal variations of a high-biomass Neotropical forest. Remote Sensing of 675 Environment 169: 93-101.

676 SANDERs, N. J., J.-P. Lessard, M. C. FitZPATRICK, and R. R. DunN. 2007. Temperature, but not 677 productivity or geometry, predicts elevational diversity gradients in ants across spatial grains. 678 Global Ecology and Biogeography 16: 640-649.

679 Schmidt, F. A., J. H. Schoereder, and M. D. N. Caetano. 2016. Ant assemblage and 680 morphological traits differ in response to soil compaction. Insectes Sociaux 64: 219-225.

681 SILVA, R. R., and C. R. F. BRANDÃO. 2014. Ecosystem-wide morphological structure of leaf-litter 682 ant communities along a tropical latitudinal gradient. PLoS ONE 9: e93049.

683 Smith, M. A., W. HallwaChS, and D. H. JanZEN. 2014. Diversity and phylogenetic community 684 structure of ants along a Costa Rican elevational gradient. Ecography 37: 720-731.

685 Stuble, K. L., S. L. Pelini, S. E. Diamond, D. A. Fowler, R. R. Dunn, and N. J. Sanders. 2013. 686 Foraging by forest ants under experimental climatic warming: a test at two sites. Ecology and 687 Evolution 3: 482-491.

688 Swenson, N. G., P. Anglada-Cordero, and J. A. Barone. 2011. Deterministic tropical tree 689 community turnover: evidence from patterns of functional beta diversity along an elevational 690 gradient. Proc. R. Soc. B. 278: 1707.

691 Tymen, B., G. Vincent, E. A. Courtois, J. Heurtebize, J. Dauzat, I. MarechauX, and J. Chave. 692 2017. Quantifying micro-environmental variation in tropical rainforest understory at landscape 693 scale by combining airborne LiDAR scanning and a sensor network. Annals of Forest Science 74: 69432. 
695 Vasconcelos, H. L., A. C. C. Macedo, and J. M. S. VilhenA. 2003. Influence of topography on 696 the distribution of ground-dwelling ants in an Amazonian forest. Studies on Neotropical Fauna and 697 Environment 38: 115-124.

698 VleminckX, J., J.-L. Doucet, J. Morin-Rivat, A. B. Biwolé, D. Bauman, O. J. Hardy, A. 699 Fayolle, J.-F. Gillet, K. Daïnou, A. Gorel and T. Drouet. 2017. The influence of spatially 700 structured soil properties on tree community assemblages at a landscape scale in the tropical forests 701 of southern Cameroon. Journal of Ecology 105: 354-366.

702 Vleminckx, J., H. Schimann, T. Decaëns, M. Fichaux, V. Vedel, G. Jaouen, M. Roy, E. 703 Lapied, J. Engel, A. Dourdain, P. Petronelli, J. Orivel and C. Baraloto. 2019. Coordinated 704 community structure among trees, fungi and invertebrate groups in Amazonian rainforests. 705 Scientific reports 9: 11337.

706 Weber, N. A. 1938. The biology of the fungus-growing ants. Part 4. Additional new forms. Part 5. 707 The Attini of Bolivia. Revista de Entomologia 7: 154-206.

708 WeISER, M. D., and M. KASPARI. 2006. Ecological morphospace of New World ants. Ecological 709 Entomology 31: 131-142.

710 Willig, M. R., D. M. Kaufman, and R. D. SteVens. 2003. Latitudinal gradients of biodiversity: 711 pattern, process, scale, and synthesis. Annual Review of Ecology, Evolution, and Systematics 34: $712 \quad 273-309$.

713 Wright, S. K., J. B. Yavitt, N. Wurzburger, B. L. Turner, E. V. J. TAnner, E. J. Sayer, L. S. 714 Santiago, M. Kaspari, L. O. Hedin, K. E. Harms, M. N. Garcia, and M. D. Corre. 2011. 715 Potassium, phosphorus, or nitrogen limit root allocation, tree growth, or litter production in a 716 lowland tropical forest. Ecology 92: 1616-1625.

717 YATES, M., H. GiBB, and N. R. AndREW. 2011. Habitat characteristics may override climatic 718 influences on ant assemblage composition: A study using a 300-km climatic gradient climatic 
1

2

3

4

5

6

7

8

9

10

11

12

13

14

15

16

17

18

19

20

21

22

23

24

25

26

27

28

29

30

31

32

33

34

35

36

37

38

39

40

41

42

43

44

45

46

47

48

49

50

51

52

53

54

55

56

57

720 Yates, M. L., N. R. ANDREW, M. BinNS, and H. GiBB. 2014. Morphological traits: predictable 721 responses to macrohabitats across a $300 \mathrm{~km}$ scale. PeerJ 2: e271.

722 
723 TABLE 1. List of morphological traits measured and their hypothesized ecological functions. WL

724 = Weber's length; HW = head width; HL = head length; PW = pronotum width; FL = femur length;

$725 \mathrm{SL}=$ scape length; $\mathrm{EL}=$ eye length; $\mathrm{CL}=$ clypeus length; $\mathrm{ML}=$ mandible length.

726

Traits Hypothesized ecological functions

WL Proxy for body size, related to several physiological and ecological traits, such as habitat use (Weber 1938, Kaspari \& Weiser 1999).

HW Indicator of mandibular musculature, related to trophic position (Kaspari 1993, Weiser \& Kaspari 2006).

HL Indicator of body size (Kaspari \& Weiser 1999) and body mass which determines the quantity of resources consumed.

PW Predictor of body mass (Kaspari \& Weiser 1999).

FL Indicator of foraging speed, related to habitat complexity (Feener Jr. et al. 1988).

SL Related to sensory abilities (Weiser \& Kaspari 2006), indicative of an ant's ability to navigate and move through its surroundings (Yates et al. 2014).

EL Indicator of feeding behavior (predatory ants have smaller eyes); hypogaeic ant species have smaller eyes compared to epigaeic ant species (Weiser \& Kaspari 2006, Yates et al. 2014).

CL Related to liquid absorption abilities (Davidson et al. 2004); clypeus length is here used as a surrogate for liquid feeding habits in ants. 
ML Longer mandibles are associated with larger prey consumption (Fowler et al. 1991). In some cases (i.e. trap-jaw ants), sublinear to linear and long mandibles are used as extremely rapid trap for hunting and killing fast preys (Gronenberg et al. 1993). 
728 TABLE 2. Taxonomic, functional and phylogenetic turnover of ant assemblages, averaged over all 729 pairs of plots (Global turnover) or for each pair of elevations (in m: 800-600, 800-400, 600-400).

$730 \quad \mathrm{I}_{\mathrm{ST}}=$ taxonomic turnover (species level); $\tau_{\mathrm{ST}}=$ functional turnover (species level); $\Pi_{\mathrm{ST}}=$ 731 phylogenetic turnover (genus level). The functional turnover was calculated using the three first 732 axes of PCA $\mathrm{ARAITS}_{\mathrm{T}}\left(\tau_{\mathrm{ST}}\right)$ and each of these axes separately $\left(\tau_{\mathrm{ST}} \mathrm{PC} 1 ; \tau_{\mathrm{ST}} \mathrm{PC} 2 ; \tau_{\mathrm{ST}} \mathrm{PC} 3\right)$. Turnover 733 values were multiplied by $10^{4}$ to facilitate the reading. Significant values are emphasized in bold 734 and with asterisks $(* * * p \leq 0.001 ; * * p \leq 0.01 ; * p \leq 0.05)$

735

\begin{tabular}{ccccc}
\hline & Global turnover & $800-600$ & $800-400$ & $600-400$ \\
\hline $\mathrm{I}_{\mathrm{ST}}$ & $\mathbf{4 0 . 9 8 * * *}$ & $\mathbf{3 6 . 3 1 *}$ & 31.83 & 17.26 \\
$\tau_{\mathrm{ST}}$ & $\mathbf{1 9 . 3 1 * *}$ & $\mathbf{1 4 . 5 1 * *}$ & $\mathbf{3 0 . 8 8} *$ & -5.46 \\
$\tau_{\mathrm{ST}} \mathrm{PC} 1$ & 10.18 & -10.44 & -9.28 & -7.79 \\
$\tau_{\mathrm{ST}} \mathrm{PC} 2$ & $\mathbf{3 6 . 2 4 * *}$ & $\mathbf{3 9 . 6 2 * *}$ & $\mathbf{9 2 . 4 1 *}$ & 0.76 \\
$\tau_{\mathrm{ST}} \mathrm{PC} 3$ & 3.20 & -9.20 & -2.01 & -9.44 \\
$\Pi_{\mathrm{ST}}$ & 1.05 & 9.10 & 7.52 & -4.68 \\
\hline
\end{tabular}


737 TABLE 3. Regression coefficients quantifying the effect on the turnover in community 738 composition $\left(\mathrm{I}_{\mathrm{ST}}=\right.$ taxonomic turnover; $\tau_{\mathrm{ST}}=$ functional turnover; $\Pi_{\mathrm{ST}}=$ phylogenetic turnover $)$, 739 of the overall environmental dissimilarity (Model 1), the dissimilarity of individual environmental

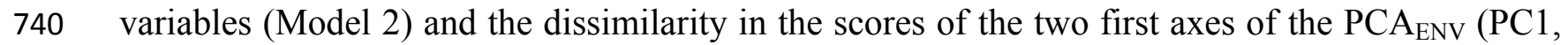
741 PC2; Model 3). For the functional turnover, the effect of environmental variables was evaluated 742 for the three first axes of PCA $\mathrm{P}_{\mathrm{TRAITS}}\left(\tau_{\mathrm{ST}}\right)$ together and for each of these axes separately $\left(\tau_{\mathrm{ST}} \mathrm{PC} 1\right.$; $\left.743 \tau_{\mathrm{ST}} \mathrm{PC} 2 ; \tau_{\mathrm{ST}} \mathrm{PC} 3\right)$. Sand $=$ percentage of sand; $\mathrm{pH}=$ soil $\mathrm{pH} ; \mathrm{OM}=$ percentage of organic matter; $\mathrm{P}$ $744=$ Olsen-phosphorus concentration; $\mathrm{RH}_{\mathrm{MEAN}}=$ mean annual relative humidity; $\mathrm{C}_{\mathrm{H}}=$ canopy height $)$.

745 Regression coefficients are multiplied by $10^{4}$ to facilitate the reading as they sometimes reach very 746 low yet significant values. Significant coefficients are emphasized in bold $(* * * \mathrm{p} \leq 0.01 ; * * \mathrm{p} \leq 0.01$; $747 * \mathrm{p} \leq 0.05 ; \uparrow \mathrm{p} \leq 0.1)$. The regression coefficients were obtained by including the spatial distance in 748 each of the three models in order to remove spatial effects (see methods).

749

\begin{tabular}{|c|c|c|c|c|c|c|}
\hline & $\mathbf{I}_{\mathbf{S T}}$ & $\tau_{\mathrm{ST}}$ & $\tau_{\mathrm{ST}} \mathrm{PC} 1$ & $\tau_{\mathrm{ST}} \mathrm{PC} 2$ & $\tau_{\mathrm{ST}} \mathrm{PC} 3$ & $\Pi_{\mathrm{ST}}$ \\
\hline \multicolumn{7}{|l|}{ Model 1} \\
\hline Global env. effect & $0.08 *$ & $0.20 * * *$ & $0.17 *$ & $0.47 * * *$ & -0.06 & -0.02 \\
\hline \multicolumn{7}{|l|}{ Model 2} \\
\hline sand & 1.55 & $10.17 \dagger$ & -0.54 & 17.08 & $14.55 *$ & -2.83 \\
\hline $\mathrm{pH}$ & -6.95 & 0.22 & $14.59 \dagger$ & -14.40 & -1.03 & $10.41 \dagger$ \\
\hline $\mathrm{OM}$ & 0.91 & -2.08 & -0.32 & 4.93 & -7.64 & -5.90 \\
\hline
\end{tabular}




\begin{tabular}{l|llllll}
$\mathrm{P}$ & $\mathbf{7 . 9 0} \dagger$ & 9.42 & $\mathbf{3 5 . 6 1 * *}$ & 3.22 & $\mathbf{- 1 3 . 5 9} \dagger$ & 2.14 \\
& & & & & & \\
$\mathrm{RH}_{\mathrm{MEAN}}$ & -7.62 & 7.75 & 21.61 & 11.26 & -11.51 & 13.15 \\
& & & & & & \\
$\mathrm{C}_{\mathrm{H}}$ & $\mathbf{2 1 . 9 9 *}$ & 15.34 & -8.14 & 43.75 & 3.40 & -13.49
\end{tabular}

Model 3

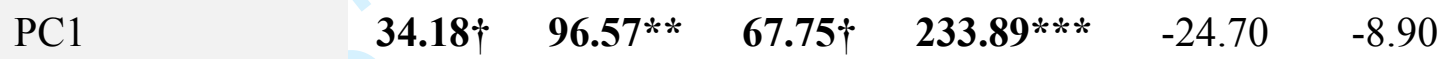

$\begin{array}{lllllll}\text { PC2 } & 9.82 & -7.09 & 28.34 & -53.53 & -2.23 & -0.37\end{array}$

750

751 
752 TABLE 4. Results from the fourth-corner analysis quantifying the strength of pairwise trait753 environment associations. Significant relationships are highlighted in bold $(* * p \leq 0.01 ; * p \leq 0.05$; $754 \uparrow \mathrm{p} \leq 0.07) . \mathrm{HL}=$ relative head length; $\mathrm{HW}=$ relative head width; $\mathrm{ML}=$ relative mandible length; $755 \mathrm{CL}=$ relative clypeus length; $\mathrm{SL}=$ relative scape length; $\mathrm{EL}=$ relative eye length; WL = Weber's 756 length; $\mathrm{FL}=$ relative femur length; $\mathrm{PW}=$ relative pronotum width; $\mathrm{PC} 1 / \mathrm{PC} 2 / \mathrm{PC} 3:$ axes 1,2 and 3 757 of the $\mathrm{PCA}_{\mathrm{TRAITS}}$; sand = percentage of sand; $\mathrm{pH}=$ soil $\mathrm{pH} ; \mathrm{OM}=$ percentage of organic matter; $\mathrm{P}$ $758=$ Olsen-phosphorus concentration; $\mathrm{RH}_{\mathrm{MEAN}}=$ mean annual relative humidity; $\mathrm{C}_{\mathrm{H}}=$ canopy height. 759

\begin{tabular}{|c|c|c|c|c|c|c|}
\hline & sand & $\mathrm{pH}$ & $\mathrm{OM}$ & $\mathrm{P}$ & $\mathrm{RH}_{\text {MEAN }}$ & $\mathrm{C}_{\mathrm{H}}$ \\
\hline HL & 0.03 & 0.05 & -0.02 & $0.07 *$ & 0.04 & -0.00 \\
\hline HW & 0.01 & 0.04 & -0.02 & 0.05 & 0.01 & -0.02 \\
\hline $\mathrm{ML}$ & 0.03 & 0.04 & -0.01 & 0.02 & 0.01 & -0.01 \\
\hline $\mathrm{CL}$ & -0.03 & 0.02 & -0.03 & 0.01 & -0.02 & 0.03 \\
\hline SL & $-0.07 *$ & 0.02 & -0.05 & -0.05 & $-0.07 *$ & 0.07 \\
\hline EL & $-0.10 * *$ & 0.00 & -0.06 & -0.08 & $-0.10 *$ & 0.09 \\
\hline WL & -0.03 & -0.04 & 0.01 & $-0.08 * *$ & -0.05 & 0.00 \\
\hline $\mathrm{FL}$ & $-0.08 \dagger$ & 0.01 & -0.05 & -0.10 & $-0.10 * *$ & 0.09 \\
\hline PW & 0.01 & 0.04 & -0.02 & 0.05 & 0.01 & -0.01 \\
\hline $\mathrm{PC} 1$ & -0.04 & -0.04 & 0.01 & $-0.08 *$ & -0.05 & 0.01 \\
\hline
\end{tabular}




\begin{tabular}{lllllll}
\hline PC2 & $\mathbf{- 0 . 0 8 *}$ & 0.03 & -0.06 & -0.06 & -0.08 & 0.09 \\
& & & & & & \\
PC3 & $\mathbf{- 0 . 0 5 *}$ & -0.02 & -0.02 & -0.02 & -0.02 & 0.02 \\
\hline
\end{tabular}

760

11

12

13

14

15

16

17

18

19

20

21

22

23

24

25

26

27

28

29

30

31

32

33

34

35

36

37

38

39

40

41

42

43

44

45

46

47

48

49

50

51

52

53

54

55

56

57

58

59

60 
761 FIGURE 1. Location of the study area and the nine sampling plots and environmental sensors at 762 Mont Itoupé. The weather sensor of Plot 6 was located halfway between Plot 5 and Plot 6 (for more 763 details, see section 2.5.2).

765 FIGURE 2. Principal Component Analysis of trait data in each plot. HL = relative head length; $766 \mathrm{HW}=$ relative head width; $\mathrm{ML}=$ relative mandible length; $\mathrm{CL}=$ relative clypeus length; $\mathrm{SL}=$ 767 relative scape length; $\mathrm{EL}=$ relative eye length; $\mathrm{WL}=$ Weber's length; FL = relative femur length; $768 \mathrm{PW}=$ relative pronotum width.

769

770 FIGURE 3. Principal Component Analysis of environmental data in each plot. Plots of the same 771 elevational band are represented by green circles $(800 \mathrm{~m})$, red squares $(600 \mathrm{~m})$ and orange triangles 772 (400m). elev = elevation $(\mathrm{m})$; sand = percentage of sand; silt = percentage of silt; clay = percentage 773 of clay; $\mathrm{pH}=$ soil $\mathrm{pH} ; \mathrm{OM}=$ percentage of organic matter; $\mathrm{C} / \mathrm{N}=$ carbon-to-nitrogen ratio; $\mathrm{P}=$ 774 Olsen-phosphorus concentration; $\mathrm{Na}=$ sodium concentration; $\mathrm{K}=$ potassium concentration; $\mathrm{T}$ _min $775=$ minimum temperature of the coldest month; T_mean = mean annual temperature; $\mathrm{RH} \_$min $=$ 776 minimum relative humidity of the driest month; $\mathrm{RH} \_$mean = mean annual relative humidity; C_cov 777 = canopy cover; $\mathrm{C}_{-} \mathrm{h}=$ canopy height; gap = gap fraction. Variables retained for analyses are 778 highlighted in blue.

779

780 
SUPPORTING INFORMATION

\section{Environmental determinants of leaf-litter ant community composition along an elevational gradient}

Mélanie Fichaux ${ }^{1 *}$, Jason Vleminckx ${ }^{1,2 *}$, Elodie A. Courtois ${ }^{3,4}$, Jacques H. C Delabie ${ }^{5,6}$, Jordan Galli $^{1,7}$, Shengli Tao ${ }^{8}$, Nicolas Labrière ${ }^{8}$, Jérôme Chave ${ }^{8}$, Christopher Baraloto $^{2}$, Jérôme Orivel ${ }^{1}$

${ }^{1}$ CNRS, UMR Ecologie des Forêts de Guyane (EcoFoG), AgroParisTech, CIRAD, INRA, Université de Guyane, Université des Antilles, Campus agronomique, BP 316, 97379, Kourou cedex, France

${ }^{2}$ Department of Biological Sciences, Florida International University 11200 S.W. 8th Street Miami, FL 33199, USA

${ }^{3}$ Laboratoire Ecologie, Evolution, Interactions des Systèmes Amazoniens (LEEISA), Université de Guyane, CNRS, IFREMER, Cayenne, France

4 Department of Biology, Centre of Excellence PLECO (Plant and Vegetation Ecology), University of Antwerp, Wilrijk, Belgium

${ }^{5}$ Laboratório de Mirmecologia, CEPEC, CEPLAC, Caixa Postal 7, Itabuna, BA 45600-970, Brazil

${ }^{6}$ Departamento de Ciências Agrárias e Ambientais, Universidade Estadual de Santa Cruz, Rodovia Jorge Amado Km 16, Ilheus, BA 45662-900, Brazil

${ }^{7}$ Naturalia Environnement, Site Agroparc, 20 rue Lawrence Durell, BP 31285, 84911 Avignon Cedex 9, France

${ }^{8}$ Laboratoire Evolution et Diversité Biologique UMR 5174, CNRS, Université Paul Sabatier, IRD, 118 route de Narbonne, 31062 Toulouse, France

* Co-first authors

Corresponding author: Mélanie Fichaux, fichaux.mel@gmail.com 
FIGURE S1. Phylogenetic tree of ant genera collected along Mont Itoupé.

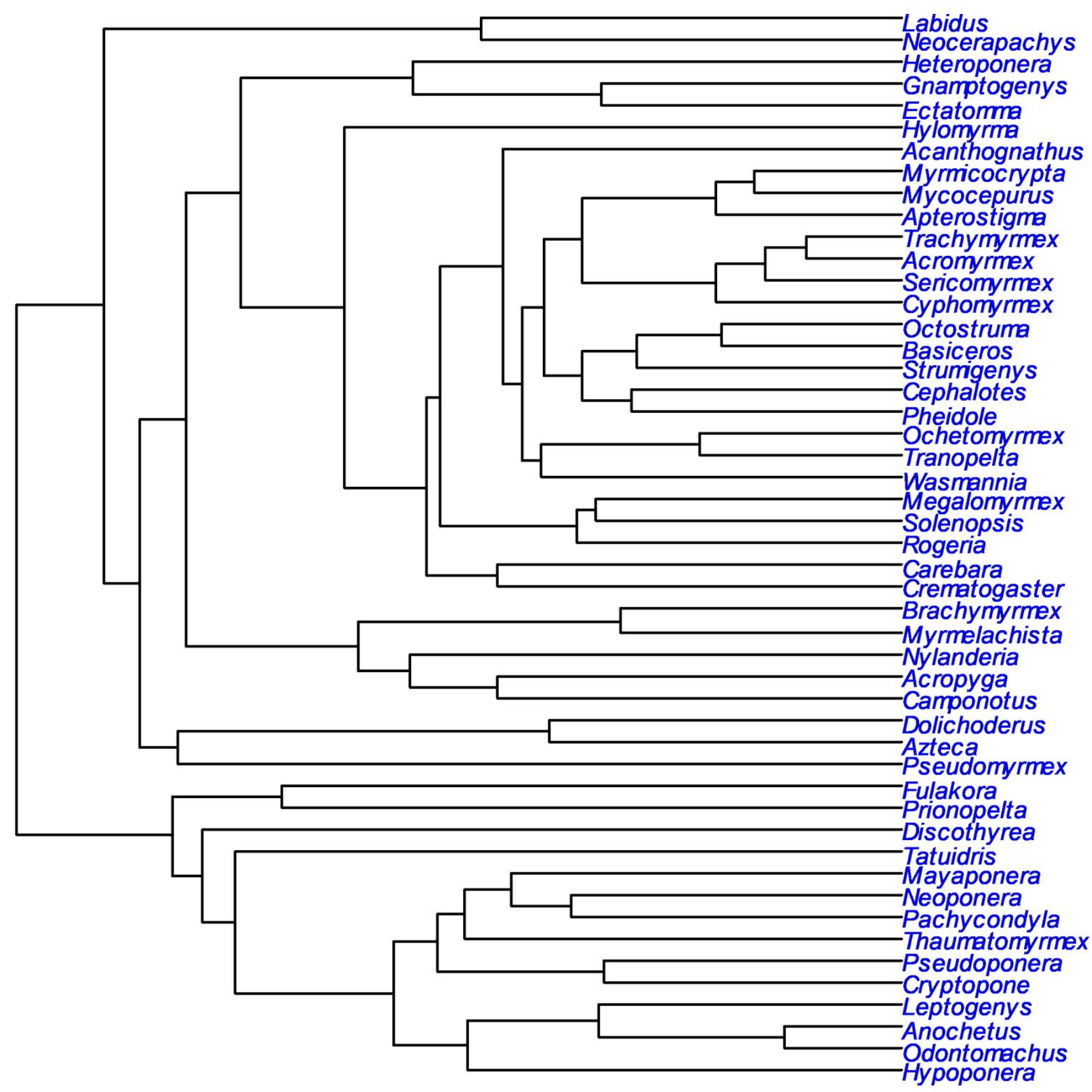




\section{FIGURE S2. Correlation plots showing correlations between the nine morphological traits.} $\mathrm{ML}=$ relative mandible length; $\mathrm{CL}=$ relative clypeus length; $\mathrm{HL}=$ relative head length; $\mathrm{HW}=$ relative head width; PW = relative pronotum width; WL = Weber's length; EL = relative eye length; $\mathrm{SL}=$ relative scape length; $\mathrm{FL}=$ relative femur length.

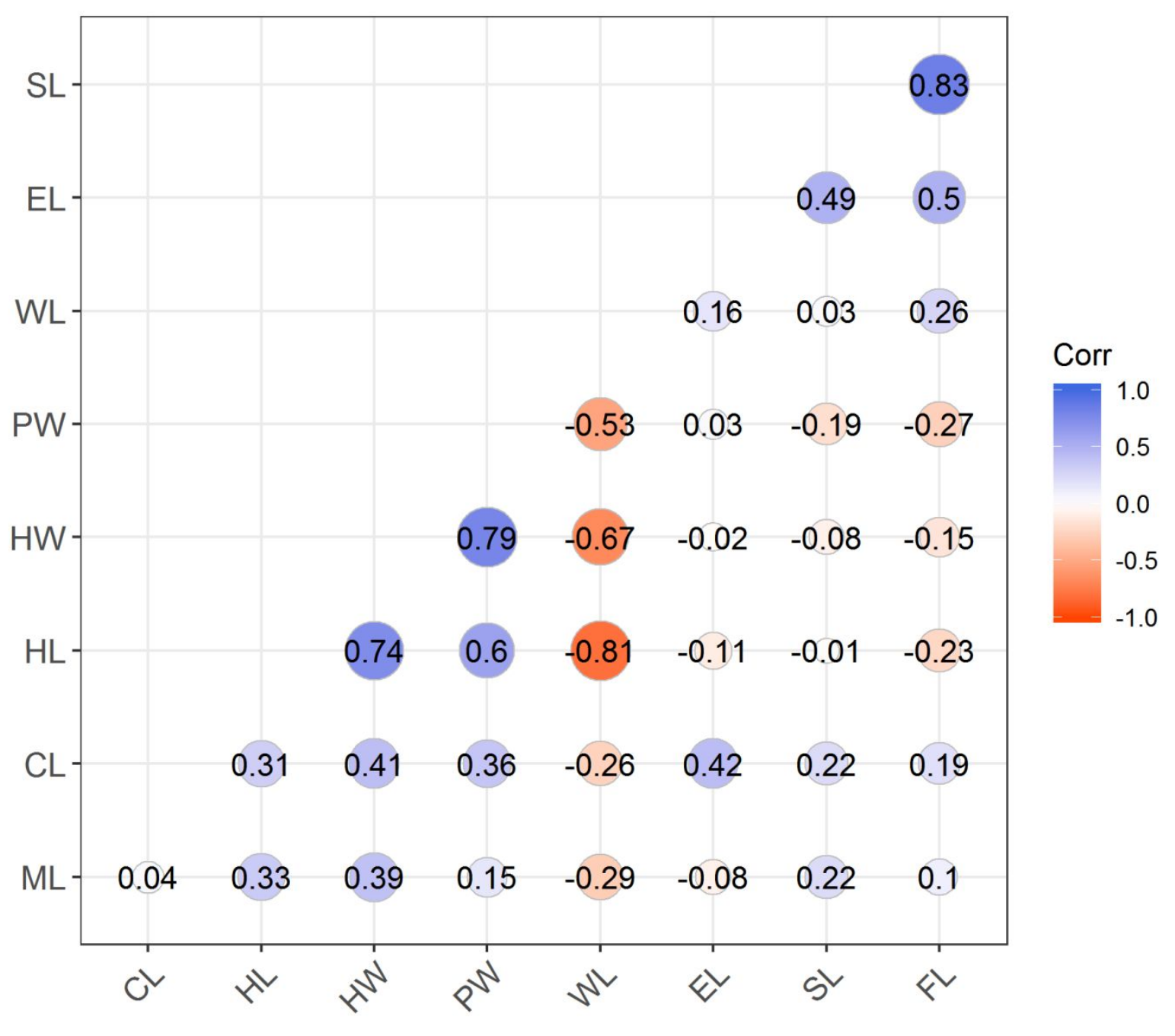


FIGURE S3. Correlation plots showing correlations between the nine soil variables. Clay = percentage of clay; sand = percentage of sand; silt = percentage of silt; $\mathrm{P}=$ Olsen-phosphorus concentration; $\mathrm{K}=$ potassium concentration; $\mathrm{Na}=$ sodium concentration; $\mathrm{C} / \mathrm{N}=$ carbon-tonitrogen ratio; $\mathrm{OM}=$ percentage of organic matter; $\mathrm{pH}=$ soil $\mathrm{pH}$.

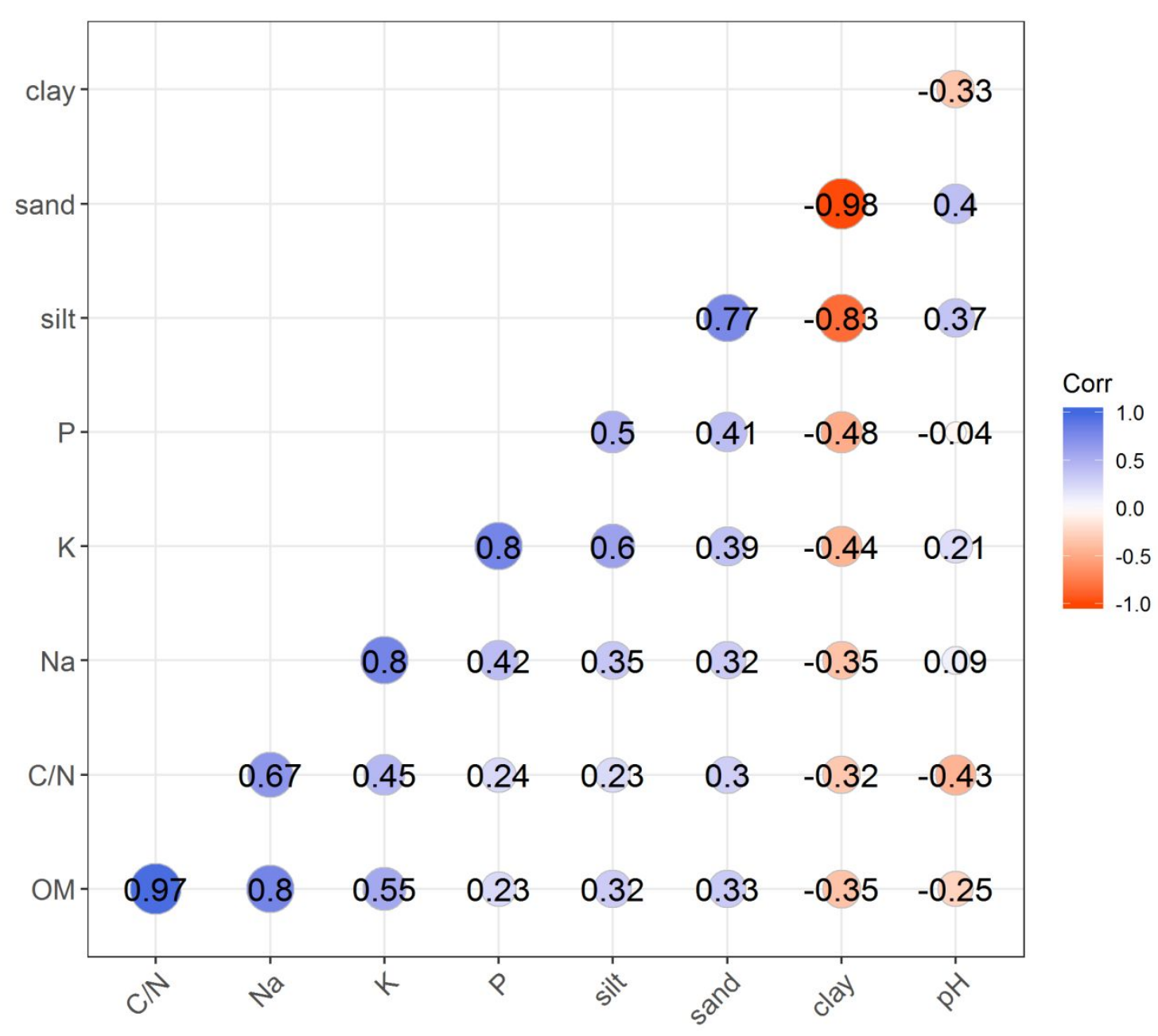


FIGURE S4. Correlation plots showing correlations between the four climatic variables. $\mathrm{T}_{\mathrm{MIN}}=$ minimum temperature of the coldest month; $\mathrm{T}_{\text {MEAN }}=$ mean annual temperature; $\mathrm{RH}_{\mathrm{MIN}}=$ minimum relative humidity of the driest month; $\mathrm{RH}_{\mathrm{MEAN}}=$ mean annual relative humidity.

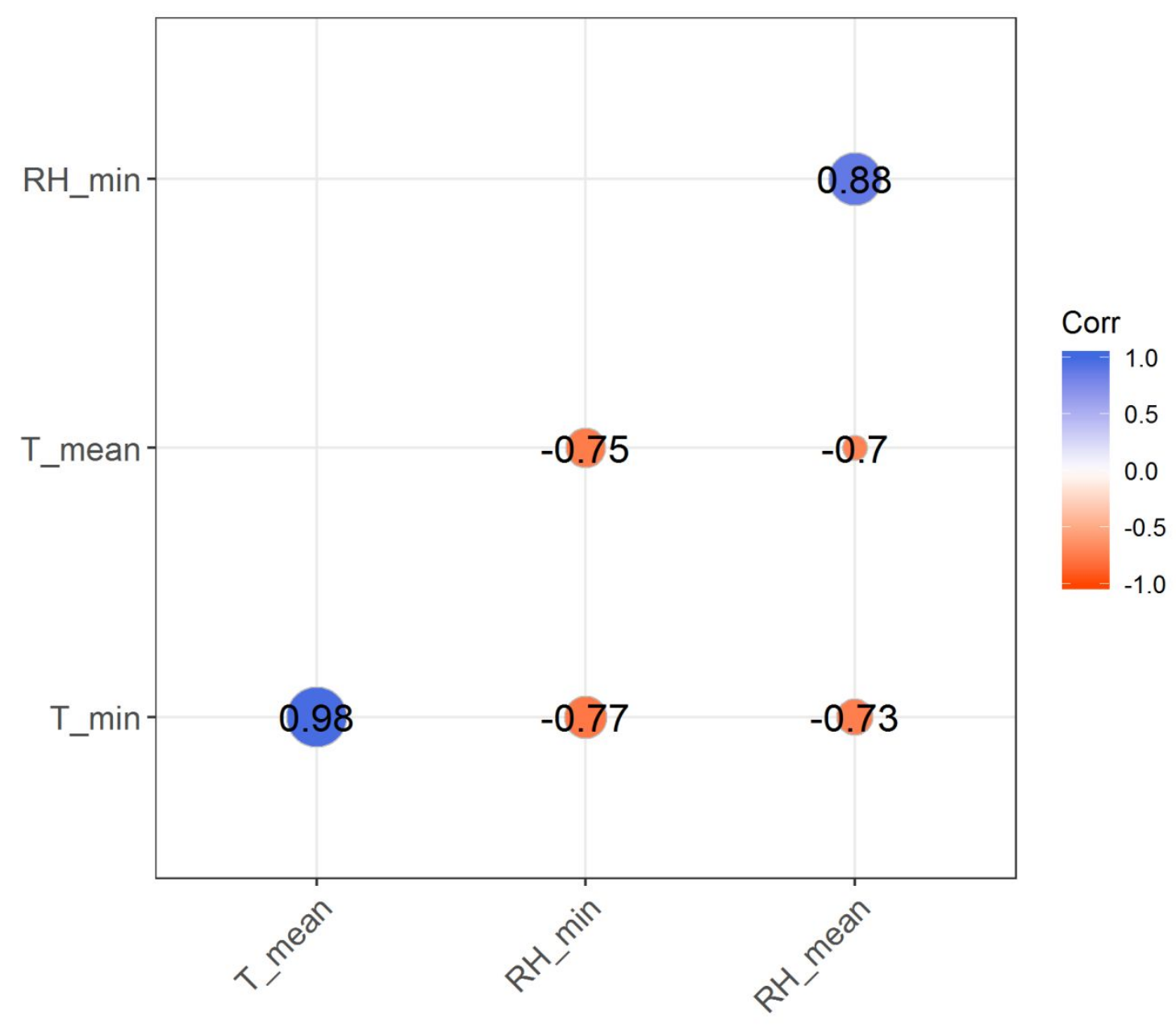


FIGURE S5. Correlation plots showing correlations between the three LiDAR-derived variables. $\mathrm{C}_{\mathrm{COV}}=$ Canopy cover; $\mathrm{C}_{\mathrm{H}}=$ Canopy height; Gap $=$ Gap fraction.

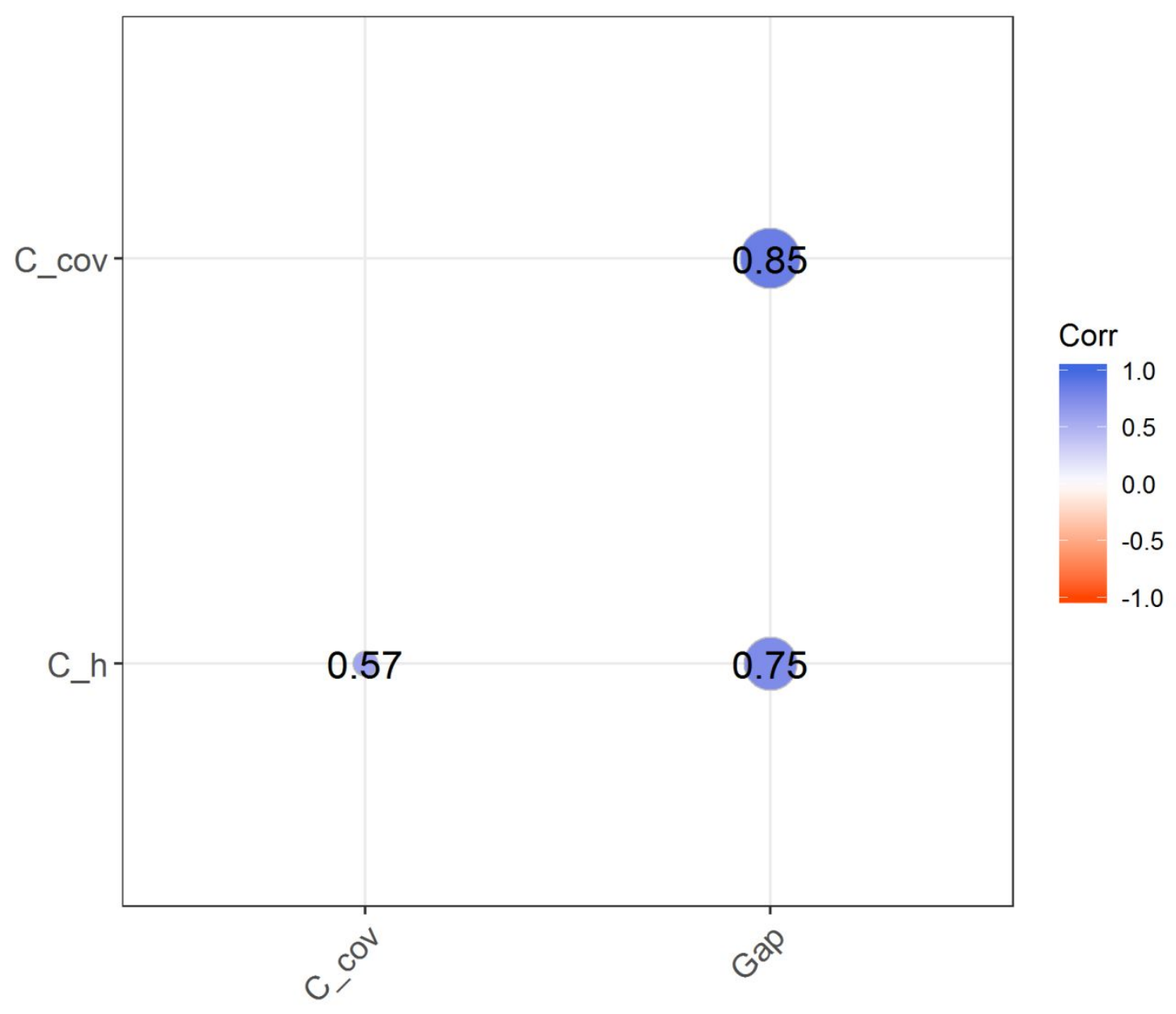


FIGURE S6. Third and fourth axis of a principal component analysis of trait data. HL = relative head length; HW = relative head width; $\mathrm{ML}=$ relative mandible length; $\mathrm{CL}=$ relative clypeus length; $\mathrm{SL}=$ relative scape length; $\mathrm{EL}=$ relative eye length; $\mathrm{WL}=$ Weber's length; $\mathrm{FL}=$ relative femur length; PW = relative pronotum width.

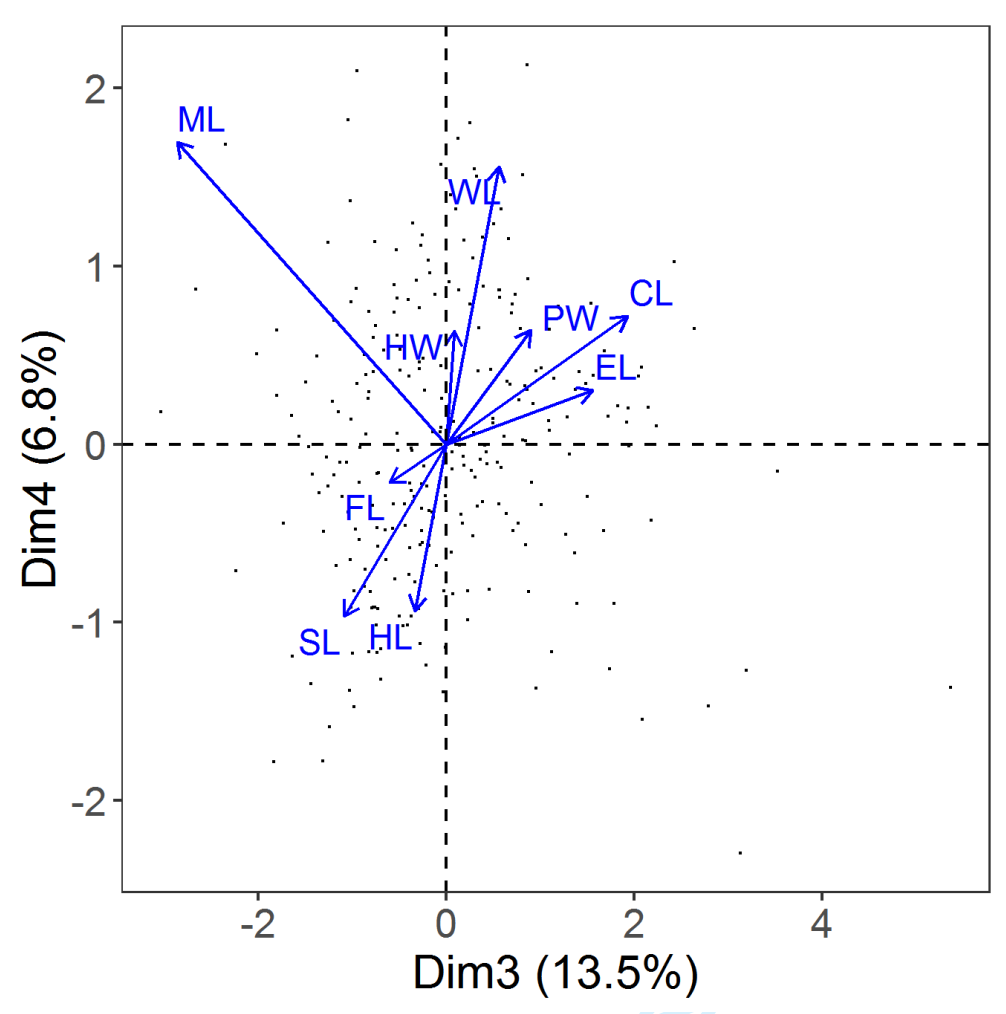


TABLE S1. Mean value of traits per species $(H L=$ head length; $H W=$ head width; $M L=$ mandible length; $\mathrm{CL}=$ clypeus length; $\mathrm{SL}=$ scape length; $\mathrm{EL}=$ eye length; $\mathrm{WL}=$ Weber's length; $\mathrm{FL}=$ femur length; $\mathrm{PW}=$ pronotum width).

\begin{tabular}{|c|c|c|c|c|c|c|c|c|c|}
\hline Species & $\mathrm{HL}$ & $\mathrm{HW}$ & $\mathrm{ML}$ & $\mathrm{CL}$ & SL & EL & WL & $\mathrm{FL}$ & PW \\
\hline Acanthognathus brevicornis & 0.83 & 0.64 & 0.94 & 0.26 & 0.63 & 0.15 & 0.79 & 0.69 & 0.41 \\
\hline Acanthognathus ocellatus & 0.77 & 0.59 & 0.76 & 0.24 & 0.74 & 0.13 & 0.76 & 0.69 & 0.39 \\
\hline Acanthognathus sp.IT14.01 & 0.80 & 0.65 & 0.67 & 0.24 & 0.68 & 0.15 & 0.81 & 0.75 & 0.42 \\
\hline Acromyrmex hystrix & 1.91 & 2.30 & 1.46 & 0.57 & 2.64 & 0.38 & 3.20 & 4.26 & 1.40 \\
\hline Acromyrmex subterraneus brunneus & 1.44 & 1.64 & 1.11 & 0.50 & 1.86 & 0.27 & 2.30 & 2.71 & 1.02 \\
\hline Acropyga decedens & 0.56 & 0.53 & 0.31 & 0.11 & 0.45 & 0.03 & 0.59 & 0.46 & 0.35 \\
\hline Acropyga exsanguis & 0.48 & 0.51 & 0.29 & 0.10 & 0.38 & 0.03 & 0.51 & 0.42 & 0.33 \\
\hline Acropyga fuhrmanni & 0.48 & 0.50 & 0.28 & 0.10 & 0.36 & 0.04 & 0.47 & 0.38 & 0.31 \\
\hline Acropyga guianensis & 0.55 & 0.50 & 0.30 & 0.12 & 0.45 & 0.03 & 0.54 & 0.45 & 0.34 \\
\hline Acropyga smithii & 0.41 & 0.40 & 0.22 & 0.07 & 0.26 & 0.03 & 0.41 & 0.25 & 0.26 \\
\hline Anochetus horridus & 1.18 & 1.02 & 1.16 & 0.24 & 1.41 & 0.22 & 1.89 & 1.49 & 0.62 \\
\hline Anochetus inermis & 1.00 & 0.95 & 0.73 & 0.26 & 1.03 & 0.16 & 1.52 & 1.12 & 0.58 \\
\hline Anochetus mayri & 0.75 & 0.76 & 0.49 & 0.20 & 0.66 & 0.09 & 1.05 & 0.72 & 0.46 \\
\hline Anochetus targionii & 0.98 & 1.02 & 0.71 & 0.15 & 0.95 & 0.16 & 1.32 & 0.96 & 0.57 \\
\hline Apterostigma acre & 0.81 & 0.65 & 0.46 & 0.16 & 0.71 & 0.13 & 1.13 & 0.91 & 0.53 \\
\hline Apterostigma auriculatum & 1.19 & 0.85 & 0.70 & 0.31 & 1.16 & 0.25 & 1.96 & 2.05 & 0.74 \\
\hline Apterostigma avium & 1.06 & 0.72 & 0.57 & 0.28 & 1.40 & 0.21 & 1.91 & 2.14 & 0.64 \\
\hline Apterostigma chocoense & 1.00 & 0.71 & 0.53 & 0.27 & 1.18 & 0.19 & 1.63 & 1.54 & 0.59 \\
\hline Apterostigma ierense & 0.97 & 0.69 & 0.51 & 0.27 & 0.92 & 0.18 & 1.28 & 1.32 & 0.73 \\
\hline Apterostigma pilosum & 0.91 & 0.66 & 0.48 & 0.20 & 0.82 & 0.15 & 1.29 & 1.18 & 0.55 \\
\hline Apterostigma robustum & 1.18 & 0.86 & 0.63 & 0.35 & 1.12 & 0.19 & 1.72 & 1.62 & 0.80 \\
\hline Azteca sp.IT14.01 & 0.65 & 0.68 & 0.33 & 0.19 & 0.57 & 0.17 & 0.77 & 0.79 & 0.44 \\
\hline Basiceros manni & 1.50 & 1.18 & 0.85 & 0.47 & 1.34 & 0.23 & 2.38 & 1.98 & 1.11 \\
\hline Basiceros militaris & 1.48 & 1.39 & 0.52 & 0.44 & 0.81 & 0.11 & 1.58 & 1.13 & 0.83 \\
\hline Brachymyrmex cavernicola & 0.56 & 0.48 & 0.28 & 0.19 & 0.59 & 0.09 & 0.62 & 0.58 & 0.34 \\
\hline Brachymyrmex pictus & 0.43 & 0.39 & 0.21 & 0.13 & 0.44 & 0.10 & 0.47 & 0.52 & 0.27 \\
\hline Brachymyrmex sp.JTL07 & 0.34 & 0.29 & 0.15 & 0.08 & 0.32 & 0.08 & 0.34 & 0.33 & 0.20 \\
\hline Camponotus atriceps & 1.97 & 1.62 & 0.86 & 0.62 & 2.38 & 0.53 & 2.86 & 2.68 & 1.30 \\
\hline Camponotus excisus & 0.98 & 0.96 & 0.42 & 0.30 & 1.05 & 0.33 & 1.25 & 1.09 & 0.82 \\
\hline Camponotus fastigatus & 1.39 & 1.17 & 0.60 & 0.43 & 1.78 & 0.36 & 2.01 & 1.84 & 1.03 \\
\hline Camponotus latangulus & 1.08 & 1.13 & 0.44 & 0.32 & 1.15 & 0.31 & 1.46 & 1.31 & 0.92 \\
\hline Camponotus linnaei & 1.34 & 1.17 & 0.54 & 0.46 & 1.73 & 0.36 & 2.04 & 1.74 & 1.22 \\
\hline Camponotus novogranadensis & 1.22 & 1.08 & 0.58 & 0.39 & 1.37 & 0.32 & 1.54 & 1.43 & 0.84 \\
\hline Camponotus rapax & 2.36 & 1.92 & 1.09 & 0.78 & 3.04 & 0.46 & 3.61 & 3.72 & 1.55 \\
\hline Camponotus salvini & 1.31 & 1.12 & 0.64 & 0.42 & 1.94 & 0.34 & 1.90 & 2.14 & 1.04 \\
\hline Camponotus simillimus & 2.11 & 1.56 & 0.89 & 0.61 & 3.07 & 0.57 & 3.36 & 3.66 & 1.29 \\
\hline Camponotus gp. Tanaemyrmex sp. 3 & 1.52 & 0.99 & 0.57 & 0.50 & 2.00 & 0.46 & 2.50 & 2.17 & 0.98 \\
\hline Carebara brevipilosa & 0.46 & 0.42 & 0.26 & 0.05 & 0.29 & 0.02 & 0.48 & 0.37 & 0.26 \\
\hline
\end{tabular}




\begin{tabular}{|c|c|c|c|c|c|c|c|c|c|}
\hline Carebara reina & 0.34 & 0.29 & 0.14 & 0.06 & 0.17 & 0.02 & 0.31 & 0.18 & 0.20 \\
\hline Carebara sp.KW14.01 & 0.29 & 0.25 & 0.14 & 0.03 & 0.16 & 0.01 & 0.29 & 0.18 & 0.15 \\
\hline Carebara urichi & 0.42 & 0.41 & 0.26 & 0.09 & 0.29 & 0.02 & 0.49 & 0.33 & 0.25 \\
\hline Crematogaster brasiliensis & 0.63 & 0.66 & 0.33 & 0.20 & 0.66 & 0.15 & 0.79 & 0.79 & 0.39 \\
\hline Crematogaster carinata & 0.56 & 0.60 & 0.29 & 0.17 & 0.57 & 0.14 & 0.68 & 0.71 & 0.37 \\
\hline Crematogaster curvispinosa & 0.58 & 0.56 & 0.29 & 0.20 & 0.51 & 0.14 & 0.63 & 0.57 & 0.37 \\
\hline Crematogaster flavosensitiva & 0.49 & 0.47 & 0.26 & 0.17 & 0.48 & 0.14 & 0.52 & 0.49 & 0.30 \\
\hline Crematogaster levior & 0.55 & 0.54 & 0.28 & 0.18 & 0.56 & 0.13 & 0.66 & 0.64 & 0.34 \\
\hline Crematogaster limata & 0.70 & 0.72 & 0.36 & 0.22 & 0.73 & 0.17 & 0.83 & 0.85 & 0.43 \\
\hline Crematogaster sotobosque & 0.49 & 0.47 & 0.27 & 0.17 & 0.52 & 0.14 & 0.58 & 0.59 & 0.33 \\
\hline Crematogaster tenuicula & 0.55 & 0.52 & 0.29 & 0.17 & 0.60 & 0.13 & 0.68 & 0.73 & 0.35 \\
\hline Crematogaster torosa & 0.74 & 0.81 & 0.36 & 0.22 & 0.53 & 0.18 & 0.85 & 0.70 & 0.47 \\
\hline Cryptopone holmgreni & 0.94 & 0.95 & 0.64 & 0.19 & 0.58 & 0.00 & 1.34 & 0.70 & 0.64 \\
\hline Cyphomyrmex peltatus & 0.51 & 0.56 & 0.30 & 0.18 & 0.51 & 0.12 & 0.74 & 0.57 & 0.37 \\
\hline Cyphomyrmex rimosus & 0.56 & 0.57 & 0.33 & 0.20 & 0.57 & 0.13 & 0.80 & 0.69 & 0.37 \\
\hline Discothyrea denticulata & 0.43 & 0.37 & 0.18 & 0.10 & 0.22 & 0.01 & 0.43 & 0.25 & 0.26 \\
\hline Discothyrea sexarticulata & 0.39 & 0.35 & 0.17 & 0.05 & 0.20 & 0.02 & 0.38 & 0.23 & 0.24 \\
\hline Dolichoderus bidens & 1.62 & 1.42 & 0.75 & 0.45 & 1.81 & 0.38 & 2.40 & 2.62 & 1.06 \\
\hline Dolichoderus bispinosus & 1.31 & 1.47 & 0.57 & 0.37 & 1.35 & 0.30 & 1.72 & 1.75 & 0.93 \\
\hline Dolichoderus gagates & 0.85 & 0.94 & 0.43 & 0.27 & 0.85 & 0.21 & 1.12 & 1.08 & 0.62 \\
\hline Dolichoderus imitator & 1.37 & 0.91 & 0.74 & 0.48 & 2.05 & 0.40 & 2.59 & 2.32 & 0.88 \\
\hline Dolichoderus lutosus & 1.16 & 1.08 & 0.48 & 0.38 & 1.04 & 0.28 & 1.54 & 1.20 & 0.62 \\
\hline Dolichoderus smithi & 1.07 & 1.03 & 0.46 & 0.39 & 0.87 & 0.29 & 1.24 & 1.20 & 0.86 \\
\hline Ectatomma edentatum & 1.82 & 1.48 & 1.21 & 0.73 & 1.78 & 0.35 & 2.94 & 2.51 & 1.20 \\
\hline Ectatomma lugens & 2.21 & 1.77 & 1.52 & 0.72 & 2.27 & 0.58 & 3.93 & 3.40 & 1.49 \\
\hline Ectatomma tuberculatum & 2.40 & 1.94 & 1.75 & 0.97 & 2.43 & 0.57 & 3.75 & 3.13 & 1.59 \\
\hline Eurhopalothrix bolaui & 0.61 & 0.66 & 0.24 & 0.21 & 0.36 & 0.08 & 0.72 & 0.55 & 0.41 \\
\hline Fulakora orizabana & 0.57 & 0.52 & 0.46 & 0.09 & 0.35 & 0.00 & 0.72 & 0.36 & 0.33 \\
\hline Gigantiops destructor & 2.18 & 2.16 & 1.21 & 0.90 & 2.52 & 1.56 & 3.25 & 4.46 & 1.12 \\
\hline Gnamptogenys acuminata & 1.02 & 0.94 & 0.66 & 0.26 & 0.85 & 0.29 & 1.61 & 1.21 & 0.83 \\
\hline Gnamptogenys annulata & 1.26 & 1.14 & 0.86 & 0.34 & 0.88 & 0.27 & 2.00 & 1.29 & 1.03 \\
\hline Gnamptogenys haenschi & 1.80 & 1.76 & 1.30 & 0.57 & 1.45 & 0.16 & 2.68 & 1.98 & 1.46 \\
\hline Gnamptogenys horni & 0.73 & 0.61 & 0.42 & 0.19 & 0.48 & 0.14 & 0.98 & 0.62 & 0.54 \\
\hline Gnamptogenys interrupta & 0.97 & 0.83 & 0.63 & 0.25 & 0.60 & 0.17 & 1.33 & 0.79 & 0.64 \\
\hline Gnamptogenys mecotyle & 1.19 & 1.12 & 0.88 & 0.32 & 1.17 & 0.29 & 1.93 & 1.36 & 1.05 \\
\hline Gnamptogenys moelleri & 1.19 & 1.00 & 0.65 & 0.36 & 1.29 & 0.21 & 1.72 & 1.63 & 0.75 \\
\hline Gnamptogenys regularis & 0.74 & 0.69 & 0.45 & 0.20 & 0.52 & 0.19 & 1.04 & 0.70 & 0.59 \\
\hline Gnamptogenys relicta & 0.67 & 0.55 & 0.35 & 0.18 & 0.49 & 0.08 & 0.85 & 0.57 & 0.44 \\
\hline Gnamptogenys sulcata & 1.14 & 1.12 & 0.76 & 0.31 & 1.01 & 0.39 & 1.90 & 1.56 & 0.86 \\
\hline Gnamptogenys tortuolosa & 1.68 & 1.51 & 1.08 & 0.46 & 1.52 & 0.43 & 2.58 & 2.02 & 1.25 \\
\hline Heteroponera flava & 0.86 & 0.74 & 0.44 & 0.28 & 0.52 & 0.19 & 1.15 & 0.68 & 0.58 \\
\hline Hylomyrma blandiens & 0.83 & 0.80 & 0.54 & 0.25 & 0.61 & 0.22 & 1.12 & 0.78 & 0.58 \\
\hline Hylomyrma immanis & 1.18 & 1.15 & 0.79 & 0.41 & 0.90 & 0.28 & 1.61 & 1.25 & 0.83 \\
\hline
\end{tabular}




\begin{tabular}{|c|c|c|c|c|c|c|c|c|c|}
\hline Hylomyrma reginae & 1.04 & 1.02 & 0.67 & 0.29 & 0.76 & 0.23 & 1.43 & 1.07 & 0.74 \\
\hline Hypoponera foreli & 0.58 & 0.52 & 0.32 & 0.10 & 0.43 & 0.03 & 0.77 & 0.47 & 0.37 \\
\hline Hypoponera sp.02.FGSGt & 0.73 & 0.65 & 0.39 & 0.19 & 0.65 & 0.04 & 1.03 & 0.70 & 0.50 \\
\hline Hypoponera sp.12.FGSGt & 0.46 & 0.36 & 0.24 & 0.08 & 0.30 & 0.02 & 0.56 & 0.31 & 0.26 \\
\hline Hypoponera sp.13.FGSGt & 0.51 & 0.44 & 0.27 & 0.09 & 0.33 & 0.04 & 0.64 & 0.40 & 0.32 \\
\hline Hypoponera sp.B & 0.89 & 0.78 & 0.51 & 0.22 & 0.77 & 0.04 & 1.30 & 0.84 & 0.61 \\
\hline Hypoponera sp.IT14.01 & 0.64 & 0.54 & 0.35 & 0.18 & 0.58 & 0.05 & 0.88 & 0.65 & 0.40 \\
\hline Hypoponera sp.IT14.02 & 0.74 & 0.69 & 0.41 & 0.18 & 0.70 & 0.04 & 1.06 & 0.72 & 0.50 \\
\hline Hypoponera sp.IT14.04 & 0.46 & 0.39 & 0.21 & 0.08 & 0.33 & 0.04 & 0.58 & 0.34 & 0.30 \\
\hline Hypoponera sp.IT14.05 & 0.59 & 0.51 & 0.32 & 0.14 & 0.47 & 0.03 & 0.82 & 0.47 & 0.40 \\
\hline Hypoponera sp.Ml15.02 & 0.62 & 0.49 & 0.32 & 0.11 & 0.45 & 0.03 & 0.83 & 0.59 & 0.38 \\
\hline Hypoponera sp.Ml15.05 & 0.82 & 0.75 & 0.46 & 0.12 & 0.70 & 0.05 & 1.17 & 0.85 & 0.55 \\
\hline Labidus coecus & 1.04 & 0.96 & 0.71 & 0.18 & 0.77 & 0.04 & 1.42 & 1.41 & 0.63 \\
\hline Leptogenys gaigei & 1.44 & 0.97 & 0.65 & 0.52 & 1.58 & 0.33 & 2.39 & 1.85 & 0.75 \\
\hline Leptogenys langi & 0.88 & 0.60 & 0.46 & 0.27 & 0.79 & 0.16 & 1.30 & 0.88 & 0.49 \\
\hline Leptogenys sp.05.FGSGt & 0.96 & 0.57 & 0.41 & 0.36 & 0.90 & 0.22 & 1.47 & 1.03 & 0.52 \\
\hline Leptogenys sp.IT14.04 & 1.14 & 0.94 & 0.74 & 0.36 & 1.17 & 0.26 & 1.83 & 1.22 & 0.73 \\
\hline Mayaponera constricta & 1.48 & 1.23 & 1.03 & 0.42 & 1.56 & 0.26 & 2.47 & 1.88 & 0.95 \\
\hline Megalomyrmex balzani & 1.97 & 1.61 & 0.99 & 0.52 & 2.66 & 0.43 & 2.81 & 3.31 & 1.18 \\
\hline Megalomyrmex drifti & 0.54 & 0.44 & 0.28 & 0.13 & 0.44 & 0.14 & 0.69 & 0.48 & 0.34 \\
\hline Megalomyrmex incisus & 0.64 & 0.54 & 0.36 & 0.17 & 0.59 & 0.20 & 0.89 & 0.78 & 0.43 \\
\hline Megalomyrmex silvestrii & 0.56 & 0.46 & 0.30 & 0.16 & 0.73 & 0.18 & 0.77 & 0.71 & 0.36 \\
\hline Megalomyrmex sp.MI15.01 & 0.78 & 0.62 & 0.42 & 0.25 & 0.79 & 0.22 & 1.18 & 0.98 & 0.52 \\
\hline Mycetophylax faunulus & 0.74 & 0.78 & 0.46 & 0.19 & 0.64 & 0.13 & 1.01 & 1.08 & 0.49 \\
\hline Mycetophylax morschi & 0.50 & 0.50 & 0.32 & 0.13 & 0.40 & 0.09 & 0.66 & 0.53 & 0.37 \\
\hline Mycetophylax strigatus & 0.66 & 0.73 & 0.41 & 0.20 & 0.65 & 0.11 & 1.01 & 0.89 & 0.45 \\
\hline Mycocepurus smithii & 0.60 & 0.62 & 0.40 & 0.15 & 0.52 & 0.12 & 0.84 & 0.63 & 0.40 \\
\hline Myrmelachista guyanensis & 0.47 & 0.47 & 0.17 & 0.11 & 0.26 & 0.10 & 0.54 & 0.32 & 0.30 \\
\hline Myrmicocrypta sp.IT14.01 & 0.68 & 0.64 & 0.48 & 0.22 & 0.63 & 0.07 & 0.92 & 0.68 & 0.44 \\
\hline Myrmicocrypta sp.IT14.02 & 0.62 & 0.53 & 0.37 & 0.12 & 0.55 & 0.06 & 0.77 & 0.62 & 0.34 \\
\hline Myrmicocrypta sp.IT14.03 & 0.64 & 0.53 & 0.39 & 0.19 & 0.64 & 0.07 & 0.78 & 0.66 & 0.36 \\
\hline Neocerapachys splendens & 0.77 & 0.58 & 0.31 & 0.15 & 0.40 & 0.04 & 0.99 & 0.56 & 0.43 \\
\hline Neoponera apicalis & 2.74 & 2.32 & 2.16 & 0.77 & 3.08 & 0.93 & 4.47 & 4.19 & 1.62 \\
\hline Neoponera commutata & 3.75 & 3.24 & 2.96 & 1.07 & 3.81 & 0.98 & 5.64 & 5.02 & 2.46 \\
\hline Neoponera crenata & 2.34 & 1.96 & 1.29 & 0.85 & 2.29 & 0.57 & 3.58 & 2.00 & 1.51 \\
\hline Neoponera foetida & 2.55 & 2.28 & 1.98 & 1.04 & 2.36 & 0.69 & 4.22 & 3.46 & 0.69 \\
\hline Neoponera procidua & 2.86 & 2.80 & 2.28 & 0.65 & 2.41 & 0.33 & 4.12 & 3.02 & 1.90 \\
\hline Neoponera verenae & 2.27 & 1.79 & 1.58 & 0.88 & 2.63 & 0.82 & 3.75 & 3.03 & 1.47 \\
\hline Nylanderia fulva & 0.69 & 0.57 & 0.35 & 0.16 & 0.89 & 0.15 & 0.88 & 0.96 & 0.43 \\
\hline Nylanderia guatemalensis & 0.64 & 0.56 & 0.33 & 0.20 & 0.78 & 0.15 & 0.81 & 0.77 & 0.41 \\
\hline Nylanderia sp.IT14.01 & 0.63 & 0.52 & 0.33 & 0.15 & 0.78 & 0.10 & 0.78 & 0.80 & 0.39 \\
\hline Nylanderia sp.SL13.03 & 0.69 & 0.58 & 0.37 & 0.17 & 0.85 & 0.16 & 0.87 & 0.89 & 0.42 \\
\hline Nylanderia steinheili & 0.54 & 0.49 & 0.26 & 0.15 & 0.69 & 0.14 & 0.69 & 0.65 & 0.35 \\
\hline
\end{tabular}




\begin{tabular}{|c|c|c|c|c|c|c|c|c|c|}
\hline Ochetomyrmex neopolitus & 0.54 & 0.51 & 0.29 & 0.17 & 0.42 & 0.13 & 0.65 & 0.49 & 0.32 \\
\hline Ochetomyrmex semipolitus & 0.51 & 0.47 & 0.29 & 0.16 & 0.35 & 0.11 & 0.55 & 0.39 & 0.30 \\
\hline Octostruma balzani & 0.48 & 0.54 & 0.18 & 0.17 & 0.27 & 0.04 & 0.54 & 0.35 & 0.33 \\
\hline Octostruma betschi & 0.46 & 0.53 & 0.20 & 0.16 & 0.28 & 0.04 & 0.54 & 0.37 & 0.33 \\
\hline Octostruma iheringi & 0.60 & 0.73 & 0.23 & 0.23 & 0.36 & 0.04 & 0.74 & 0.50 & 0.42 \\
\hline Octostruma obtusidens & 0.58 & 0.70 & 0.23 & 0.18 & 0.35 & 0.05 & 0.78 & 0.53 & 0.47 \\
\hline Octostruma sp.JTL035 & 0.52 & 0.64 & 0.21 & 0.18 & 0.31 & 0.04 & 0.69 & 0.43 & 0.37 \\
\hline Odontomachus caelatus & 3.22 & 2.72 & 1.95 & 0.61 & 3.09 & 0.52 & 3.81 & 3.55 & 1.56 \\
\hline Odontomachus chelifer & 3.84 & 2.63 & 2.32 & 0.60 & 3.96 & 0.66 & 4.71 & 4.71 & 1.51 \\
\hline Odontomachus haematodus & 2.42 & 1.93 & 1.47 & 0.41 & 2.28 & 0.42 & 2.87 & 2.44 & 1.09 \\
\hline Odontomachus laticeps & 2.39 & 1.86 & 1.45 & 0.42 & 2.11 & 0.39 & 3.01 & 2.61 & 1.01 \\
\hline Odontomachus meinerti & 1.94 & 1.53 & 1.16 & 0.32 & 1.82 & 0.30 & 2.14 & 1.87 & 0.91 \\
\hline Odontomachus scalptus & 2.66 & 2.14 & 1.59 & 0.45 & 2.64 & 0.47 & 3.24 & 2.91 & 1.14 \\
\hline Pachycondyla crassinoda & 3.79 & 3.70 & 2.64 & 0.87 & 3.42 & 0.74 & 5.67 & 4.21 & 2.68 \\
\hline Pachycondyla harpax & 1.70 & 1.73 & 1.08 & 0.38 & 1.43 & 0.31 & 2.54 & 1.71 & 1.24 \\
\hline Pachycondyla impressa & 2.91 & 2.80 & 1.94 & 0.61 & 2.46 & 0.52 & 4.15 & 2.95 & 2.08 \\
\hline Pachycondyla nr. lenkoi & 2.13 & 2.00 & 1.33 & 0.50 & 1.73 & 0.31 & 2.79 & 1.92 & 1.41 \\
\hline Pheidole aenescens & 0.65 & 0.55 & 0.38 & 0.17 & 0.92 & 0.16 & 0.87 & 1.01 & 0.38 \\
\hline Pheidole alienata & 0.63 & 0.59 & 0.40 & 0.18 & 0.89 & 0.14 & 0.79 & 1.07 & 0.38 \\
\hline Pheidole allarmata & 0.54 & 0.57 & 0.45 & 0.13 & 0.61 & 0.08 & 0.74 & 0.61 & 0.38 \\
\hline Pheidole araneoides & 0.89 & 0.68 & 0.53 & 0.25 & 1.35 & 0.18 & 1.36 & 1.59 & 0.53 \\
\hline Pheidole biconstricta & 0.82 & 0.73 & 0.52 & 0.24 & 1.00 & 0.16 & 1.09 & 1.18 & 0.48 \\
\hline Pheidole bruesi & 0.56 & 0.51 & 0.33 & 0.18 & 0.66 & 0.12 & 0.70 & 0.68 & 0.34 \\
\hline Pheidole bulliceps & 0.72 & 0.62 & 0.46 & 0.20 & 0.94 & 0.16 & 1.00 & 1.08 & 0.43 \\
\hline Pheidole cataractae & 0.51 & 0.48 & 0.31 & 0.16 & 0.69 & 0.11 & 0.67 & 0.74 & 0.29 \\
\hline Pheidole coffeicola & 0.60 & 0.49 & 0.34 & 0.16 & 0.86 & 0.14 & 0.83 & 0.96 & 0.35 \\
\hline Pheidole cramptoni & 0.54 & 0.51 & 0.32 & 0.16 & 0.48 & 0.11 & 0.65 & 0.65 & 0.34 \\
\hline Pheidole cursor & 0.60 & 0.48 & 0.36 & 0.17 & 0.84 & 0.14 & 0.82 & 0.90 & 0.35 \\
\hline Pheidole deima & 0.72 & 0.80 & 0.51 & 0.22 & 0.70 & 0.15 & 0.98 & 1.00 & 0.53 \\
\hline Pheidole embolopyx & 0.57 & 0.49 & 0.33 & 0.16 & 0.71 & 0.13 & 0.75 & 0.77 & 0.34 \\
\hline Pheidole fissiceps & 0.61 & 0.49 & 0.35 & 0.16 & 0.89 & 0.15 & 0.85 & 0.95 & 0.35 \\
\hline Pheidole flavens & 0.40 & 0.38 & 0.24 & 0.12 & 0.35 & 0.08 & 0.44 & 0.35 & 0.25 \\
\hline Pheidole fracticeps & 0.41 & 0.41 & 0.23 & 0.13 & 0.33 & 0.09 & 0.49 & 0.40 & 0.23 \\
\hline Pheidole gemmula & 0.42 & 0.41 & 0.24 & 0.14 & 0.33 & 0.08 & 0.42 & 0.36 & 0.25 \\
\hline Pheidole gp. fallax sp.D & 0.59 & 0.56 & 0.44 & 0.16 & 0.80 & 0.12 & 0.84 & 0.94 & 0.38 \\
\hline Pheidole gp. fallax sp.F & 0.64 & 0.58 & 0.37 & 0.18 & 0.88 & 0.16 & 0.88 & 0.98 & 0.39 \\
\hline Pheidole gp. tristis sp.B3 & 0.53 & 0.52 & 0.34 & 0.13 & 0.49 & 0.09 & 0.62 & 0.60 & 0.32 \\
\hline Pheidole gp. tristis sp.C & 0.45 & 0.41 & 0.28 & 0.13 & 0.46 & 0.09 & 0.56 & 0.47 & 0.27 \\
\hline Pheidole gp. tristis sp.D & 0.61 & 0.56 & 0.43 & 0.17 & 0.81 & 0.11 & 0.85 & 0.88 & 0.38 \\
\hline Pheidole gp. tristis sp.H1 & 0.52 & 0.51 & 0.34 & 0.14 & 0.52 & 0.10 & 0.68 & 0.58 & 0.33 \\
\hline Pheidole guajirana & 0.39 & 0.37 & 0.22 & 0.13 & 0.33 & 0.08 & 0.46 & 0.36 & 0.23 \\
\hline Pheidole jeannei & 0.57 & 0.56 & 0.37 & 0.17 & 0.64 & 0.12 & 0.68 & 0.73 & 0.34 \\
\hline Pheidole lattkei & 0.59 & 0.48 & 0.34 & 0.14 & 0.91 & 0.14 & 0.85 & 1.02 & 0.34 \\
\hline
\end{tabular}




\begin{tabular}{|c|c|c|c|c|c|c|c|c|c|}
\hline Pheidole longiseta & 0.63 & 0.57 & 0.37 & 0.18 & 0.81 & 0.15 & 0.81 & 0.89 & 0.39 \\
\hline Pheidole lovejoyi & 0.62 & 0.49 & 0.36 & 0.17 & 0.99 & 0.15 & 0.94 & 1.10 & 0.36 \\
\hline Pheidole meinertopsis & 0.44 & 0.45 & 0.27 & 0.13 & 0.42 & 0.09 & 0.53 & 0.46 & 0.29 \\
\hline Pheidole microps & 0.52 & 0.51 & 0.35 & 0.13 & 0.46 & 0.05 & 0.64 & 0.51 & 0.34 \\
\hline Pheidole midas & 0.61 & 0.56 & 0.35 & 0.19 & 0.71 & 0.12 & 0.73 & 0.72 & 0.36 \\
\hline Pheidole nana & 0.52 & 0.50 & 0.33 & 0.13 & 0.49 & 0.07 & 0.61 & 0.59 & 0.33 \\
\hline Pheidole neoschultzi & 0.34 & 0.33 & 0.18 & 0.09 & 0.29 & 0.08 & 0.36 & 0.30 & 0.21 \\
\hline Pheidole nitella & 0.36 & 0.34 & 0.21 & 0.11 & 0.31 & 0.08 & 0.41 & 0.31 & 0.22 \\
\hline Pheidole nr. araneoides & 0.74 & 0.59 & 0.45 & 0.20 & 1.51 & 0.17 & 1.18 & 1.67 & 0.44 \\
\hline Pheidole nr. cramptoni & 0.53 & 0.50 & 0.32 & 0.14 & 0.46 & 0.11 & 0.64 & 0.53 & 0.33 \\
\hline Pheidole nr. fimbriata sp.A & 0.68 & 0.67 & 0.53 & 0.18 & 0.74 & 0.14 & 0.98 & 0.85 & 0.46 \\
\hline Pheidole nr. fimbriata sp.C & 0.58 & 0.59 & 0.42 & 0.16 & 0.58 & 0.13 & 0.73 & 0.71 & 0.39 \\
\hline Pheidole nr. fimbriata sp.D & 0.42 & 0.41 & 0.26 & 0.12 & 0.40 & 0.08 & 0.49 & 0.46 & 0.26 \\
\hline Pheidole nr. sagax & 0.61 & 0.59 & 0.34 & 0.17 & 0.71 & 0.14 & 0.79 & 0.78 & 0.38 \\
\hline Pheidole nr. seeldrayersii & 0.60 & 0.57 & 0.35 & 0.17 & 0.80 & 0.15 & 0.81 & 0.87 & 0.37 \\
\hline Pheidole nr. subarmata & 0.38 & 0.36 & 0.23 & 0.11 & 0.32 & 0.09 & 0.44 & 0.34 & 0.23 \\
\hline Pheidole nr. tristis & 0.59 & 0.59 & 0.44 & 0.17 & 0.62 & 0.12 & 0.81 & 0.79 & 0.39 \\
\hline Pheidole pedana & 0.37 & 0.37 & 0.21 & 0.12 & 0.27 & 0.08 & 0.41 & 0.30 & 0.24 \\
\hline Pheidole rugiceps & 0.52 & 0.46 & 0.32 & 0.14 & 0.70 & 0.11 & 0.66 & 0.78 & 0.30 \\
\hline Pheidole sagax & 0.56 & 0.52 & 0.33 & 0.17 & 0.68 & 0.13 & 0.73 & 0.72 & 0.34 \\
\hline Pheidole sculptior & 0.43 & 0.40 & 0.27 & 0.12 & 0.41 & 0.09 & 0.47 & 0.45 & 0.27 \\
\hline Pheidole sp.IT14.01 & 0.75 & 0.75 & 0.52 & 0.23 & 0.75 & 0.13 & 1.00 & 0.98 & 0.47 \\
\hline Pheidole sp.IT14.08 & 0.42 & 0.43 & 0.23 & 0.12 & 0.34 & 0.08 & 0.43 & 0.34 & 0.25 \\
\hline Pheidole sp.MI15.06 & 0.44 & 0.41 & 0.25 & 0.14 & 0.41 & 0.09 & 0.49 & 0.49 & 0.25 \\
\hline Pheidole subarmata & 0.43 & 0.41 & 0.28 & 0.13 & 0.43 & 0.09 & 0.55 & 0.47 & 0.27 \\
\hline Pheidole terribilis & 0.74 & 0.82 & 0.64 & 0.19 & 0.87 & 0.16 & 1.15 & 0.95 & 0.56 \\
\hline Pheidole tristis & 0.73 & 0.68 & 0.47 & 0.23 & 0.73 & 0.13 & 0.96 & 0.91 & 0.44 \\
\hline Pheidole zelata & 0.66 & 0.63 & 0.39 & 0.19 & 0.86 & 0.15 & 0.86 & 1.04 & 0.41 \\
\hline Pheidole zeteki & 0.42 & 0.42 & 0.20 & 0.12 & 0.29 & 0.08 & 0.40 & 0.29 & 0.23 \\
\hline Platythyrea pilosula & 1.51 & 1.23 & 0.76 & 0.41 & 1.11 & 0.42 & 2.31 & 1.61 & 1.09 \\
\hline Prionopelta amabilis & 0.53 & 0.46 & 0.26 & 0.09 & 0.29 & 0.03 & 0.67 & 0.33 & 0.31 \\
\hline Procryptocerus scabriusculus & 1.30 & 1.40 & 0.49 & 0.35 & 0.86 & 0.33 & 1.68 & 1.04 & 1.08 \\
\hline Procryptocerus schmitti & 0.87 & 0.88 & 0.27 & 0.27 & 0.57 & 0.27 & 1.11 & 0.61 & 0.64 \\
\hline Procryptocerus sp.IT14.01 & 1.50 & 1.52 & 0.30 & 0.43 & 0.87 & 0.40 & 1.89 & 1.11 & 1.12 \\
\hline Pseudomyrmex tenuis & 1.27 & 1.13 & 0.52 & 0.20 & 0.60 & 0.83 & 1.78 & 1.18 & 0.72 \\
\hline Pseudoponera stigma & 1.01 & 0.99 & 0.65 & 0.24 & 0.75 & 0.09 & 1.48 & 0.85 & 0.71 \\
\hline Pseudoponera succedanea & 0.86 & 0.81 & 0.53 & 0.24 & 0.60 & 0.10 & 1.23 & 0.69 & 0.58 \\
\hline Rasopone arhuaca & 1.28 & 1.13 & 0.86 & 0.23 & 1.03 & 0.16 & 1.85 & 1.27 & 0.88 \\
\hline Rasopone sp.JTL047 & 1.29 & 1.23 & 0.82 & 0.21 & 0.95 & 0.14 & 1.82 & 1.06 & 0.95 \\
\hline Rhopalothrix sp.JTL014 & 0.34 & 0.41 & 0.16 & 0.12 & 0.20 & 0.01 & 0.46 & 0.29 & 0.28 \\
\hline Rogeria besucheti & 0.69 & 0.64 & 0.36 & 0.21 & 0.47 & 0.08 & 0.75 & 0.49 & 0.46 \\
\hline Rogeria blanda & 0.81 & 0.74 & 0.42 & 0.25 & 0.55 & 0.14 & 1.05 & 0.70 & 0.57 \\
\hline Rogeria germaini & 0.76 & 0.67 & 0.35 & 0.16 & 0.53 & 0.08 & 0.84 & 0.63 & 0.49 \\
\hline
\end{tabular}




\begin{tabular}{|c|c|c|c|c|c|c|c|c|c|}
\hline Rogeria innotabilis & 0.60 & 0.52 & 0.28 & 0.08 & 0.40 & 0.08 & 0.62 & 0.52 & 0.35 \\
\hline Rogeria scobinata & 0.55 & 0.48 & 0.27 & 0.16 & 0.35 & 0.08 & 0.59 & 0.41 & 0.35 \\
\hline Rogeria sp.IT14.01 & 0.45 & 0.38 & 0.22 & 0.10 & 0.30 & 0.03 & 0.47 & 0.33 & 0.29 \\
\hline Rogeria sp.IT14.06 & 0.50 & 0.44 & 0.25 & 0.10 & 0.33 & 0.03 & 0.51 & 0.35 & 0.31 \\
\hline Rogeria sp.SL13.01 & 0.54 & 0.49 & 0.26 & 0.09 & 0.36 & 0.07 & 0.56 & 0.43 & 0.34 \\
\hline Rogeria subarmata & 0.77 & 0.67 & 0.34 & 0.16 & 0.50 & 0.15 & 0.88 & 0.66 & 0.50 \\
\hline Sericomyrmex bondari & 0.96 & 1.27 & 0.69 & 0.32 & 0.86 & 0.18 & 1.53 & 1.28 & 0.80 \\
\hline Sericomyrmex mayri & 1.11 & 1.48 & 0.79 & 0.33 & 0.90 & 0.20 & 1.65 & 1.55 & 0.98 \\
\hline Sericomyrmex parvulus & 0.78 & 0.97 & 0.56 & 0.24 & 0.62 & 0.15 & 1.15 & 0.93 & 0.63 \\
\hline Solenopsis bicolor & 0.52 & 0.45 & 0.23 & 0.10 & 0.31 & 0.05 & 0.56 & 0.41 & 0.30 \\
\hline Solenopsis sp.01 & 0.49 & 0.42 & 0.26 & 0.09 & 0.40 & 0.05 & 0.57 & 0.46 & 0.29 \\
\hline Solenopsis sp.02 & 0.47 & 0.40 & 0.23 & 0.07 & 0.34 & 0.05 & 0.57 & 0.44 & 0.26 \\
\hline Solenopsis sp.03 & 0.46 & 0.39 & 0.24 & 0.07 & 0.28 & 0.04 & 0.50 & 0.31 & 0.26 \\
\hline Solenopsis sp.09 & 0.59 & 0.54 & 0.25 & 0.11 & 0.36 & 0.05 & 0.67 & 0.48 & 0.36 \\
\hline Solenopsis sp.11 & 0.34 & 0.30 & 0.15 & 0.06 & 0.18 & 0.04 & 0.35 & 0.18 & 0.20 \\
\hline Solenopsis sp.12 & 0.40 & 0.34 & 0.21 & 0.07 & 0.26 & 0.04 & 0.44 & 0.27 & 0.23 \\
\hline Solenopsis sp.13 & 0.39 & 0.33 & 0.17 & 0.06 & 0.22 & 0.04 & 0.42 & 0.25 & 0.22 \\
\hline Solenopsis sp.14 & 0.35 & 0.30 & 0.18 & 0.04 & 0.24 & 0.04 & 0.40 & 0.27 & 0.20 \\
\hline Solenopsis sp.15 & 0.38 & 0.31 & 0.19 & 0.07 & 0.26 & 0.04 & 0.42 & 0.28 & 0.21 \\
\hline Solenopsis sp.17 & 0.42 & 0.35 & 0.19 & 0.08 & 0.27 & 0.04 & 0.45 & 0.30 & 0.23 \\
\hline Solenopsis sp.21 & 0.34 & 0.28 & 0.16 & 0.05 & 0.22 & 0.03 & 0.35 & 0.23 & 0.19 \\
\hline Solenopsis sp.23 & 0.41 & 0.34 & 0.21 & 0.06 & 0.29 & 0.03 & 0.42 & 0.34 & 0.22 \\
\hline Solenopsis sp.24 & 0.34 & 0.27 & 0.15 & 0.06 & 0.17 & 0.04 & 0.34 & 0.19 & 0.18 \\
\hline Solenopsis sp.25 & 0.30 & 0.24 & 0.14 & 0.04 & 0.16 & 0.03 & 0.30 & 0.18 & 0.15 \\
\hline Solenopsis sp.28 & 0.48 & 0.41 & 0.22 & 0.09 & 0.34 & 0.05 & 0.52 & 0.38 & 0.26 \\
\hline Solenopsis virulens & 0.83 & 0.78 & 0.44 & 0.24 & 0.74 & 0.12 & 1.08 & 0.99 & 0.50 \\
\hline Strumigenys auctidens & 0.47 & 0.36 & 0.19 & 0.15 & 0.17 & 0.05 & 0.48 & 0.27 & 0.25 \\
\hline Strumigenys beebei & 0.55 & 0.39 & 0.14 & 0.16 & 0.26 & 0.08 & 0.57 & 0.33 & 0.26 \\
\hline Strumigenys borgmeieri & 0.69 & 0.48 & 0.48 & 0.21 & 0.57 & 0.09 & 0.77 & 0.72 & 0.34 \\
\hline Strumigenys cincinnata & 0.45 & 0.33 & 0.10 & 0.15 & 0.22 & 0.04 & 0.45 & 0.31 & 0.21 \\
\hline Strumigenys cosmostela & 0.48 & 0.44 & 0.32 & 0.11 & 0.32 & 0.05 & 0.57 & 0.39 & 0.28 \\
\hline Strumigenys crassicornis & 0.48 & 0.40 & 0.20 & 0.15 & 0.24 & 0.05 & 0.49 & 0.36 & 0.27 \\
\hline Strumigenys denticulata & 0.41 & 0.35 & 0.36 & 0.12 & 0.27 & 0.04 & 0.46 & 0.30 & 0.24 \\
\hline Strumigenys diabola & 0.73 & 0.70 & 1.11 & 0.23 & 0.75 & 0.09 & 0.89 & 0.83 & 0.42 \\
\hline Strumigenys dyseides & 0.38 & 0.32 & 0.24 & 0.09 & 0.25 & 0.02 & 0.38 & 0.29 & 0.21 \\
\hline Strumigenys elongata & 0.54 & 0.48 & 0.41 & 0.13 & 0.47 & 0.05 & 0.61 & 0.46 & 0.30 \\
\hline Strumigenys perparva & 0.36 & 0.33 & 0.22 & 0.10 & 0.24 & 0.04 & 0.39 & 0.26 & 0.21 \\
\hline Strumigenys schulzi & 0.46 & 0.38 & 0.12 & 0.17 & 0.24 & 0.06 & 0.50 & 0.32 & 0.25 \\
\hline Strumigenys smithii & 0.59 & 0.58 & 0.43 & 0.16 & 0.49 & 0.08 & 0.75 & 0.62 & 0.37 \\
\hline Strumigenys spathula & 0.52 & 0.49 & 0.36 & 0.12 & 0.42 & 0.05 & 0.59 & 0.44 & 0.27 \\
\hline Strumigenys subedentata & 0.46 & 0.44 & 0.32 & 0.11 & 0.21 & 0.06 & 0.53 & 0.39 & 0.27 \\
\hline Strumigenys trinidadensis & 0.67 & 0.65 & 0.55 & 0.18 & 0.59 & 0.11 & 0.85 & 0.73 & 0.38 \\
\hline Strumigenys trudifera & 0.65 & 0.51 & 0.77 & 0.18 & 0.57 & 0.04 & 0.70 & 0.65 & 0.32 \\
\hline
\end{tabular}




\begin{tabular}{llllllllll}
\hline Strumigenys villiersi & 0.48 & 0.35 & 0.16 & 0.15 & 0.25 & 0.05 & 0.57 & 0.37 & 0.22 \\
Strumigenys waiwai & 0.31 & 0.27 & 0.20 & 0.07 & 0.22 & 0.03 & 0.36 & 0.22 & 0.18 \\
Tatuidris tatusia & 0.67 & 0.86 & 0.37 & 0.18 & 0.33 & 0.05 & 0.72 & 0.41 & 0.55 \\
Thaumatomyrmex soesilae & 0.65 & 0.80 & 0.79 & 0.17 & 0.59 & 0.19 & 1.04 & 0.76 & 0.53 \\
Trachymyrmex cornetzi & 0.73 & 0.79 & 0.50 & 0.21 & 0.75 & 0.14 & 1.11 & 1.00 & 0.52 \\
Trachymyrmex farinosus & 1.01 & 1.23 & 0.77 & 0.32 & 0.92 & 0.21 & 1.63 & 1.48 & 0.81 \\
Trachymyrmex mandibularis & 1.02 & 1.34 & 0.78 & 0.30 & 1.21 & 0.22 & 1.57 & 1.61 & 0.78 \\
Trachymyrmex nr. farinosus & 1.22 & 1.34 & 0.87 & 0.40 & 1.11 & 0.25 & 1.48 & 1.64 & 0.88 \\
Trachymyrmex sp.A & 1.27 & 1.50 & 0.92 & 0.38 & 1.14 & 0.26 & 2.06 & 1.90 & 1.02 \\
Trachymyrmex sp.B & 0.94 & 1.01 & 0.71 & 0.27 & 0.89 & 0.19 & 1.51 & 1.39 & 0.68 \\
Tranopelta gilva & 0.64 & 0.63 & 0.38 & 0.19 & 0.42 & 0.06 & 0.76 & 0.52 & 0.42 \\
Typhlomyrmex pusillus & 0.43 & 0.36 & 0.22 & 0.11 & 0.27 & 0.01 & 0.57 & 0.27 & 0.26 \\
Wasmannia auropunctata & 0.45 & 0.40 & 0.20 & 0.14 & 0.37 & 0.11 & 0.46 & 0.44 & 0.27 \\
Wasmannia rochai & 0.49 & 0.49 & 0.24 & 0.17 & 0.40 & 0.11 & 0.55 & 0.44 & 0.33 \\
\hline
\end{tabular}


TABLE S2. Leaf-litter ant sampling plots, coordinates, elevation and environmental parameters measured in the study. Lat. = latitude; long. = longitude; elev. = elevation (m); sand = percentage of sand; silt = percentage of silt; clay = percentage of clay; $\mathrm{pH}=$ soil $\mathrm{pH} ; \mathrm{OM}=$ percentage of organic matter; $\mathrm{C} / \mathrm{N}=$ carbon-to-nitrogen ratio; $\mathrm{P}=$ Olsen-phosphorus concentration; Na $=$ sodium concentration; $\mathrm{K}=$ potassium concentration; $\mathrm{T}_{\mathrm{MIN}}=$ minimum temperature of the coldest month; $\mathrm{T}_{\mathrm{MEAN}}=$ mean annual temperature; $\mathrm{RH}_{\mathrm{MIN}}=$ minimum relative humidity of the driest month; $\mathrm{RH}_{\text {MEAN }}=$ mean annual relative humidity; $\mathrm{C}_{\mathrm{COV}}=$ canopy cover; $\mathrm{C}_{\mathrm{H}}=$ canopy height; gap = gap fraction. Variables retained for analyses are highlighted in bold.

\begin{tabular}{|c|c|c|c|c|c|c|c|c|c|c|c|c|c|c|c|c|c|c|c|c|}
\hline 12 & Plot & lat. & long. & elev. & sand & silt & clay & $\mathrm{pH}$ & OM & $\mathrm{C} / \mathrm{N}$ & $\mathbf{P}$ & $\mathrm{Na}$ & $\mathrm{K}$ & $\mathrm{T}_{\mathrm{MIN}}$ & $\mathrm{T}_{\text {MEAN }}$ & $\mathrm{RH}_{\mathrm{MIN}}$ & $\mathbf{R H}_{\text {MEAN }}$ & $\mathrm{C}_{\mathrm{cov}}$ & $\mathrm{C}_{\mathrm{H}}$ & gap \\
\hline 13 & IT-01 & -53.08 & 3.03 & 818.85 & 22.47 & 32.77 & 44.76 & 4.54 & 8.16 & 12.96 & 2.27 & 3.66 & 0.12 & 17.44 & 21.08 & 69.34 & 99.54 & 0.98 & 21.05 & 0.85 \\
\hline & IT-02 & -53.08 & 3.02 & 822.86 & 29.42 & 29.77 & 40.81 & 4.60 & 9.35 & 13.07 & 2.53 & 4.15 & 0.13 & 17.65 & 20.99 & 64.77 & 99.18 & 1.00 & 22.69 & 0.91 \\
\hline 16 & IT-03 & -53.09 & 3.02 & 801.74 & 28.57 & 9.00 & 62.44 & 4.74 & 6.13 & 12.87 & 1.73 & 2.77 & 0.09 & 17.68 & 21.18 & 71.13 & 99.27 & 0.99 & 20.36 & 0.88 \\
\hline 1 & IT-05 & -53.10 & 3.02 & 578.16 & 15.78 & 9.31 & 74.91 & 4.73 & 5.68 & 12.13 & 1.20 & 2.72 & 0.08 & 19.72 & 22.67 & 54.38 & 95.41 & 1.00 & 32.53 & 0.96 \\
\hline 20 & IT-06 & -53.10 & 3.01 & 623.70 & 8.98 & 11.83 & 79.92 & 4.61 & 5.83 & 12.61 & 1.53 & 2.69 & 0.09 & 19.32 & 22.27 & 58.23 & 96.56 & 1.00 & 34.20 & 0.95 \\
\hline 21 & IT-07 & -53.11 & 3.03 & 464.55 & 6.70 & 6.44 & 86.85 & 4.47 & 4.66 & 12.11 & 1.80 & 2.24 & 0.08 & 20.34 & 23.21 & 57.53 & 96.86 & 0.99 & 32.15 & 0.94 \\
\hline & IT-09 & -53.11 & 3.02 & 422.30 & 8.16 & 8.64 & 83.21 & 5.66 & 5.14 & 9.77 & 1.80 & 3.06 & 0.10 & 20.44 & 23.36 & 58.08 & 95.83 & 1.00 & 37.09 & 0.97 \\
\hline
\end{tabular}


TABLE S3. Number of occurrences of species collected at each elevation (between 0 and 60 per elevation), according to their classification. A dash indicates the absence of a species at an elevation.

\begin{tabular}{lccc}
\hline Species occurrences at each elevation & $400 \mathrm{~m}$ & $600 \mathrm{~m}$ & $800 \mathrm{~m}$ \\
\hline Subfamily AGROECOMYRMECINAE Carpenter, 1930 & & & \\
\hline Tribe Agroecomyrmecini Carpenter, 1930 & & & - \\
$\quad$ Tatuidris tatusia Brown \& Kempf, 1968 & 1 & 2 & \\
\hline Subfamily AMBLYOPONINAE Forel, 1893 & & & - \\
\hline Tribe Amblyoponini Forel, 1893 & & & - \\
$\quad$ Fulakora orizabana (Brown, 1960) & 1 & - & 26 \\
\hline Prionopelta amabilis Borgmeier, 1949 & 8 & 5 &
\end{tabular}

Subfamily DOLICHODERINAE Forel, 1878

Tribe Dolichoderini Forel, 1878

Azteca sp.IT14.01

Dolichoderus bidens (Linnaeus, 1758)

Dolichoderus bispinosus (Olivier, 1792)

Dolichoderus gagates Emery, 1890

Dolichoderus imitator Emery, 1894

Dolichoderus lutosus (Smith, 1858)

Dolichoderus smithi MacKay, 1993

Subfamily DORYLINAE Leach, 1815

Tribe Cerapachyini Forel, 1893

Neocerapachys splendens (Borgmeier, 1957)

$\begin{array}{lll}- & 2 & 1\end{array}$

Tribe Ecitonini Forel, 1893

Labidus coecus (Latreille, 1802)

5

5

3

Subfamily ECTATOMMINAE Emery, 1895

Tribe Ectatommini Emery, 1895

Ectatomma edentatum Roger, 1863

12

5

3

Ectatomma lugens Emery, 1894

Ectatomma tuberculatum (Olivier, 1792)

Gnamptogenys acuminata (Emery, 1896)

Gnamptogenys annulata (Mayr, 1887)

Gnamptogenys haenschi (Emery, 1902)

21

20

Gnamptogenys horni (Santschi, 1929)

Gnamptogenys interrupta (Mayr, 1887)

Gnamptogenys mecotyle Brown, 1958

Gnamptogenys moelleri (Forel, 1912)

Gnamptogenys regularis Mayr, 1870

Gnamptogenys relicta (Mann, 1916)

Gnamptogenys sulcata (Smith, 1858)

Gnamptogenys tortuolosa (Smith, 1858)

$\begin{array}{ccc}- & 1 & 2 \\ - & - & 1 \\ 1 & 2 & 3 \\ 13 & 12 & 11 \\ 1 & - & - \\ 1 & - & 1 \\ 1 & 5 & 9 \\ - & 1 & - \\ - & - & 1 \\ 1 & - & - \\ - & 1 & -\end{array}$

Tribe Typhlomyrmecini Emery, 1911 
Typhlomyrmex pusillus Emery, 1894

Subfamily FORMICINAE Latreille, 1809

Tribe Camponotini Forel, 1878

Camponotus atriceps (Smith, 1858)

Camponotus excisus Mayr, 1870

Camponotus fastigatus Roger, 1863

Camponotus latangulus Roger, 1863

Camponotus linnaei Forel, 1886

Camponotus novogranadensis Mayr, 1870

Camponotus rapax (Fabricius, 1804)

Camponotus salvini Forel, 1899

Camponotus simillimus (Smith, 1862)

Camponotus gp. Tanaemyrmex sp.3

Tribe Gigantiopini Ashmead, 1905

Gigantiops destructor (Fabricius, 1804)

Tribe Lasiini Ashmead, 1905

Acropyga decedens (Mayr, 1887)

Acropyga exsanguis (Wheeler, 1909)

Acropyga fuhrmanni (Forel, 1914)

Acropyga guianensis Weber, 1944

Acropyga smithii Forel, 1893

Tribe Myrmelachistini Forel, 1912

Myrmelachista guyanensis Wheeler, 1934

Tribe Plagiolepidini Forel, 1886

Brachymyrmex cavernicola Wheeler, 1938

Brachymyrmex pictus Mayr, 1887

Brachymyrmex sp.JTL07

Nylanderia fulva (Mayr, 1862)

Nylanderia guatemalensis (Forel, 1885)

Nylanderia sp.IT14.01

Nylanderia sp.SL13.03

Nylanderia steinheili (Forel, 1893)

$\begin{array}{ccc}15 & 23 & 1 \\ 1 & - & - \\ 1 & 2 & 2 \\ - & 1 & - \\ 1 & 1 & - \\ 24 & 12 & - \\ 1 & 4 & - \\ 1 & - & - \\ - & - & 2 \\ 1 & - & -\end{array}$

Subfamily HETEROPONERINAE Bolton, 2003

Tribe Heteroponerini Bolton, 2003

Heteroponera flava Kempf, 1962

2

Subfamily MYRMICINAE Lepeletier de Saint-Fargeau, 1835

Tribe Attini Smith, 1858

Acanthognathus brevicornis Smith, 1944

Acanthognathus ocellatus Mayr, 1887

Acanthognathus sp.IT14.01

Acromyrmex hystrix (Latreille, 1802)

Acromyrmex subterraneus brunneus (Forel, 1912)

Apterostigma acre Lattke, 1997

$\begin{array}{ccc}8 & 7 & 4 \\ 1 & - & - \\ 4 & 2 & 2 \\ 1 & - & - \\ 10 & 2 & 15 \\ 3 & 1 & - \\ 1 & 1 & 2 \\ 27 & 24 & 8\end{array}$

$\begin{array}{lll}- & 1 & 2 \\ 1 & - & - \\ - & 1 & 1 \\ - & 1 & - \\ 8 & 2 & -\end{array}$

2

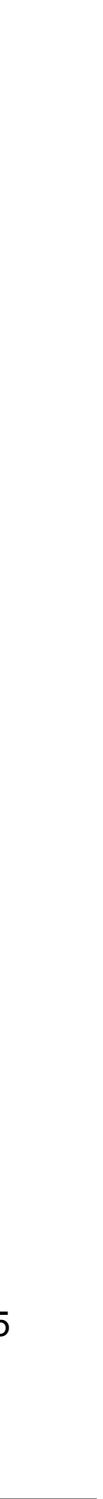

27 
Apterostigma auriculatum Wheeler, 1925

Apterostigma avium Lattke, 1997

Apterostigma chocoense Lattke, 1997

Apterostigma ierense Weber, 1937

Apterostigma pilosum Mayr, 1865

Apterostigma robustum Emery, 1896

Basiceros manni Brown \& Kempf, 1960

Basiceros militaris (Weber, 1950)

Cyphomyrmex peltatus Kempf, 1966

Cyphomyrmex rimosus (Spinola, 1851)

Eurhopalothrix bolaui (Mayr, 1870)

Mycetophylax faunulus (Wheeler, 1925)

Mycetophylax morschi (Emery, 1888)

Mycetophylax strigatus (Mayr, 1887)

Mycocepurus smithii (Forel, 1893)

Myrmicocrypta sp.IT14.01

Myrmicocrypta sp.IT14.02

Myrmicocrypta sp.IT14.03

Octostruma balzani (Emery, 1894)

Octostruma betschi Perrault, 1988

Octostruma iheringi (Emery, 1888)

Octostruma obtusidens Longino, 2013

Octostruma sp.JTL035

Procryptocerus scabriusculus Forel, 1899

Procryptocerus schmitti Forel, 1901

Procryptocerus sp.IT14.01

Rhopalothrix sp.JTL014

Sericomyrmex bondari Borgmeier, 1937

Sericomyrmex mayri Forel, 1912

Sericomyrmex parvulus Forel, 1912

Trachymyrmex cornetzi (Forel, 1912)

Trachymyrmex farinosus (Emery, 1894)

Trachymyrmex mandibularis Weber, 1938

Trachymyrmex nr. farinosus

Trachymyrmex sp.A

Trachymyrmex sp.B

Tranopelta gilva Mayr, 1866

3

Wasmannia auropunctata (Roger, 1863)

Wasmannia rochai Forel, 1912
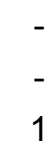
Crematogaster flavosensitiva Longino, 2003

Crematogaster levior Longino, 2003

Crematogaster limata Smith, 1858

Crematogaster sotobosque Longino, 2003

Crematogaster tenuicula Forel, 1904

Crematogaster torosa Mayr, 1870

Tribe Dacetini Forel, 1892

Strumigenys auctidens (Bolton, 2000)

Strumigenys beebei (Wheeler, 1915)

Strumigenys borgmeieri Brown, 1954

Strumigenys cincinnata (Kempf, 1975)

Strumigenys cosmostela Kempf, 1975

Strumigenys crassicornis Mayr, 1887

Strumigenys denticulata Mayr, 1887

Strumigenys diabola Bolton, 2000

Strumigenys dyseides Bolton, 2000

Strumigenys elongata Roger, 1863

Strumigenys perparva Brown, 1958

Strumigenys schulzi Emery, 1894

Strumigenys smithii Forel, 1886

Strumigenys spathula Lattke \& Goitía, 1997

Strumigenys subedentata Mayr, 1887

Strumigenys trinidadensis Wheeler, 1922

Strumigenys trudifera Kempf \& Brown, 1969

Strumigenys villiersi (Perrault, 1986)

Strumigenys waiwai (Sosa-Calvo et al., 2010)

Tribe Formicoxenini Forel, 1893

Ochetomyrmex neopolitus Fernández, 2003

Ochetomyrmex semipolitus Mayr, 1878

$\begin{array}{ccc}16 & 21 & 11 \\ 7 & 5 & 2\end{array}$

Tribe Pheidolini Emery, 1877

Pheidole aenescens Wilson, 2003

Pheidole alienata Borgmeier, 1929

Pheidole allarmata Wilson, 2003

Pheidole araneoides Wilson, 2003

Pheidole biconstricta Mayr, 1870

Pheidole bruesi Wheeler, 1911

Pheidole bulliceps Wilson, 2003

Pheidole cataractae Wheeler, 1916

Pheidole coffeicola Borgmeier, 1934

Pheidole cramptoni Wheeler, 1916

Pheidole cursor Wilson, 2003

Pheidole deima Wilson, 2003

Pheidole embolopyx Brown, 1968

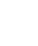

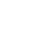

-


Pheidole fissiceps Wilson, 2003

Pheidole flavens Roger, 1863

Pheidole fracticeps Wilson, 2003

Pheidole gemmula Wilson, 2003

37

Pheidole gp. fallax sp.D

Pheidole gp. fallax sp.F

Pheidole gp. tristis sp.B3

Pheidole gp. tristis sp.C

Pheidole gp. tristis sp.D

Pheidole gp. tristis sp.H1

Pheidole guajirana Wilson, 2003

Pheidole jeannei Wilson, 2003

Pheidole lattkei Wilson, 2003

Pheidole longiseta Wilson, 2003

Pheidole lovejoyi Wilson, 2003

Pheidole meinertopsis Wilson, 2003

Pheidole microps Wilson, 2003

Pheidole midas Wilson, 2003

Pheidole nana Emery, 1894

Pheidole neoschultzi LaPolla, 2006

Pheidole nitella Wilson, 2003

Pheidole nr. araneoides

Pheidole nr. cramptoni

Pheidole nr. fimbriata sp.A

Pheidole nr. fimbriata sp.C

Pheidole nr. fimbriata sp.D

Pheidole nr. sagax

Pheidole nr. seeldrayersii

Pheidole nr. subarmata

Pheidole nr. tristis

Pheidole pedana Wilson, 2003

Pheidole rugiceps Wilson, 2003

Pheidole sagax Wilson, 2003

Pheidole sculptior Forel, 1893

Pheidole sp.IT14.01

Pheidole sp.IT14.08

Pheidole sp.MI15.06

Pheidole subarmata Mayr, 1884

$\begin{array}{lll}- & 20 & 5\end{array}$

Pheidole terribilis Wilson, 2003

Pheidole tristis (Smith, 1858)

Pheidole zelata Wilson, 2003

Pheidole zeteki Smith, 1947

Tribe Pogonomyrmecini Ward et al., 2015 
Hylomyrma blandiens Kempf, 1961

Hylomyrma immanis Kempf, 1973

11

Hylomyrma reginae Kutter, 1977

Tribe Solenopsidini Forel, 1893

Carebara brevipilosa Fernández, 2004

Carebara reina Fernández, 2004

Carebara sp.KW14.01

Carebara urichi (Wheeler, 1922)

Megalomyrmex balzani Emery, 1894

Megalomyrmex drifti Kempf, 1961

Megalomyrmex incisus Smith, 1947

Megalomyrmex silvestrii Wheeler, 1909

Megalomyrmex sp.MI15.01

Rogeria besucheti Kugler, 1994

Rogeria blanda (Smith, 1858)

Rogeria germaini Emery, 1894

Rogeria innotabilis Kugler, 1994

Rogeria scobinata Kugler, 1994

Rogeria sp.IT14.01

Rogeria sp.IT14.06

Rogeria sp.SL13.01

Rogeria subarmata (Kempf, 1961)

Solenopsis bicolor (Emery, 1906)

Solenopsis sp.01

Solenopsis sp.02

Solenopsis sp.03

Solenopsis sp.09

Solenopsis sp.11

Solenopsis sp.12

Solenopsis sp.13

Solenopsis sp.14

Solenopsis sp.15

Solenopsis sp.17

Solenopsis sp.21

Solenopsis sp.23

Solenopsis sp.24

Solenopsis sp. 25

Solenopsis sp.28

Solenopsis virulens (Smith, 1858)

\begin{tabular}{|c|c|c|}
\hline 2 & 2 & - \\
\hline 8 & 5 & 9 \\
\hline 7 & 6 & 17 \\
\hline 8 & 6 & 4 \\
\hline 3 & - & 2 \\
\hline 2 & - & 1 \\
\hline - & 1 & 1 \\
\hline 2 & 3 & 2 \\
\hline 1 & - & - \\
\hline - & - & 1 \\
\hline 1 & - & 1 \\
\hline - & - & 2 \\
\hline 1 & - & 2 \\
\hline 5 & - & - \\
\hline 3 & - & - \\
\hline 1 & - & - \\
\hline 10 & - & - \\
\hline- & 1 & - \\
\hline 7 & 2 & - \\
\hline 7 & 21 & 23 \\
\hline 1 & 4 & 2 \\
\hline 15 & 26 & 7 \\
\hline 4 & 2 & 1 \\
\hline 32 & 2 & 23 \\
\hline 23 & 3 & 5 \\
\hline 37 & 38 & 20 \\
\hline 7 & 3 & 17 \\
\hline 46 & 50 & 54 \\
\hline 13 & 5 & 1 \\
\hline 21 & 12 & 12 \\
\hline 4 & 3 & 4 \\
\hline 7 & 5 & 2 \\
\hline 5 & - & - \\
\hline 1 & 2 & - \\
\hline 7 & 2 & 9 \\
\hline
\end{tabular}

Subfamily PONERINAE Lepeletier de Saint-Fargeau, 1835

Tribe Ponerini Lepeletier de Saint-Fargeau, 1835

Anochetus horridus Kempf, 1964

Anochetus inermis André, 1889 
Anochetus mayri Emery, 1884

Anochetus targionii Emery, 1894

Cryptopone holmgreni (Wheeler, 1925)

Hypoponera foreli (Mayr, 1887)

Hypoponera sp.02.FGSGt

Hypoponera sp.12.FGSGt

Hypoponera sp.13.FGSGt

Hypoponera sp.B

Hypoponera sp.IT14.01

Hypoponera sp.IT14.02

Hypoponera sp.IT14.04

Hypoponera sp.IT14.05

Hypoponera sp.Ml15.02

Hypoponera sp.Ml15.05

Leptogenys gaigei Wheeler, 1923

Leptogenys langi Wheeler, 1923

Leptogenys sp.05.FGSGt

Leptogenys sp.IT14.04

Mayaponera constricta (Mayr, 1884)

Neoponera apicalis (Latreille, 1802)

Neoponera commutata (Roger, 1860)

Neoponera crenata (Roger, 1861)

Neoponera foetida (Linnaeus, 1758)

Neoponera procidua (Emery, 1890)

Neoponera verenae Forel, 1922

Odontomachus caelatus Brown, 1976

Odontomachus chelifer (Latreille, 1802)

Odontomachus haematodus (Linnaeus, 1758)

Odontomachus laticeps Roger, 1861

Odontomachus meinerti Forel, 1905

Odontomachus scalptus Brown, 1978

Pachycondyla crassinoda (Latreille, 1802)

Pachycondyla harpax (Fabricius, 1804)

Pachycondyla impressa (Roger, 1861)

Pachycondyla nr. lenkoi

Platythyrea pilosula (Smith, 1858)

Pseudoponera stigma (Fabricius, 1804)

Pseudoponera succedanea (Roger, 1863)

Rasopone arhuaca (Forel, 1901)

Rasopone sp.JTL047

Thaumatomyrmex soesilae Makhan, 2007

3

Subfamily PROCERATIINAE Emery, 1895

Tribe Proceratiini Emery, 1895 
1

2

3

4

5

6

7

8

9

10

11

12

13

14

15

16

17

18

19

20

21

22

23

24

25

26

27

28

29

30

31

32

33

34

35

36

37

38

39

40

41

42

43

44

45

46

47

48

49

50

51

52

53

54

55

56

57

58

59

60
Discothyrea denticulata Weber, 1939

Discothyrea sexarticulata Borgmeier, 1954

Subfamily PSEUDOMYRMECINAE Smith, 1952

Tribe Pseudomyrmecini Smith, 1952

Pseudomyrmex tenuis (Fabricius, 1804)

$\begin{array}{ccc}1 & 1 & 1 \\ 11 & 1 & 7\end{array}$

$\begin{array}{lll}11 & 1 & 7\end{array}$

7

3 
TABLE S4. Eigenvalues and trait loadings of the three first axes of a PCA performed on the matrix of mean trait values for each species (PCA TRAITS $_{\text {) }}$

\begin{tabular}{l|c|c|c}
\hline & Axis 1 & Axis 2 & Axis 3 \\
\hline Eigenvalue & 3.46 & 2.33 & 1.21 \\
Percentage of variance & 38.38 & 25.58 & 13.48 \\
Cumulative percentage of variance & 38.38 & 63.96 & 77.44 \\
Trait loadings & & & \\
- Weber's length & -0.83 & -0.08 & 0.15 \\
- Relative head width & 0.89 & 0.21 & 0.02 \\
- Relative head length & 0.88 & 0.17 & -0.09 \\
- Relative pronotum width & 0.80 & 0.10 & 0.24 \\
- Relative femur length & -0.44 & 0.81 & -0.17 \\
- Relative scape length & -0.27 & 0.83 & -0.29 \\
- Relative eye length & -0.27 & 0.70 & 0.42 \\
- Relative clypeus length & 0.35 & 0.55 & 0.52 \\
- Relative mandible length & 0.30 & 0.28 & -0.76 \\
\hline
\end{tabular}




\section{TABLE S5. Eigenvalues and trait loadings of the two first axes of a PCA performed on the matrix of the 17 environmental variables measured at each plot $\left(\mathrm{PCA}_{\mathrm{ENV}}\right)$. $\mathrm{T}_{\mathrm{MIN}}=$ minimum temperature of the coldest month; $\mathrm{T}_{\mathrm{MEAN}}=$ mean annual temperature; Gap $=$ Gap fraction; $\mathrm{C}_{\mathrm{H}}=$ Canopy height; $\mathrm{C}_{\mathrm{COV}}=$ Canopy cover; Clay $=$ percentage of clay; $\mathrm{pH}=$ soil $\mathrm{pH} ;$ Silt $=$ percentage of silt; Phosphorus $=$ Olsen-phosphorus concentration; sand = percentage of sand; $\mathrm{K}=$ potassium concentration; $\mathrm{C} / \mathrm{N}=$ carbon-to-nitrogen ratio; $\mathrm{Na}=$ sodium concentration; $\mathrm{OM}=$ percentage of organic matter; $\mathrm{RH}_{\mathrm{MIN}}=$ minimum relative humidity of the driest month; $\mathrm{RH}_{\mathrm{MEAN}}$ $=$ mean annual relative humidity. The variables retained for analyses are highlighted in bold.}

\begin{tabular}{|c|c|c|}
\hline 30 & Axis 1 & Axis 2 \\
\hline Eigenvalue & 10.28 & 3.52 \\
\hline Percentage of variance & 60.45 & 20.70 \\
\hline Cumulative percentage of variance & 60.45 & 81.15 \\
\hline \multicolumn{3}{|l|}{ Trait loadings } \\
\hline$-T_{M I N}$ & -0.98 & 0.01 \\
\hline$-T_{\text {MEAN }}$ & -0.97 & 0.15 \\
\hline - Gap & -0.92 & 0.01 \\
\hline$-\mathbf{C}_{\mathrm{H}}$ & -0.90 & 0.38 \\
\hline$-\mathrm{C}_{\mathrm{cov}}$ & -0.86 & -0.04 \\
\hline - Clay & -0.58 & -0.73 \\
\hline$-\quad \mathrm{pH}$ & -0.42 & 0.85 \\
\hline - Silt & 0.54 & 0.70 \\
\hline - Phosphorus & 0.59 & 0.54 \\
\hline - Sand & 0.60 & 0.57 \\
\hline$-\quad K$ & 0.63 & 0.48 \\
\hline$-\quad \mathrm{C} / \mathrm{N}$ & 0.68 & -0.69 \\
\hline$-\mathrm{Na}$ & 0.72 & 0.12 \\
\hline$-\quad O M$ & 0.77 & -0.43 \\
\hline$-\quad \mathrm{RH}_{\mathrm{MIN}}$ & 0.89 & 0.07 \\
\hline - Elevation & 0.91 & -0.30 \\
\hline$-\quad \mathbf{R H}_{\text {MEAN }}$ & 0.93 & 0.00 \\
\hline
\end{tabular}




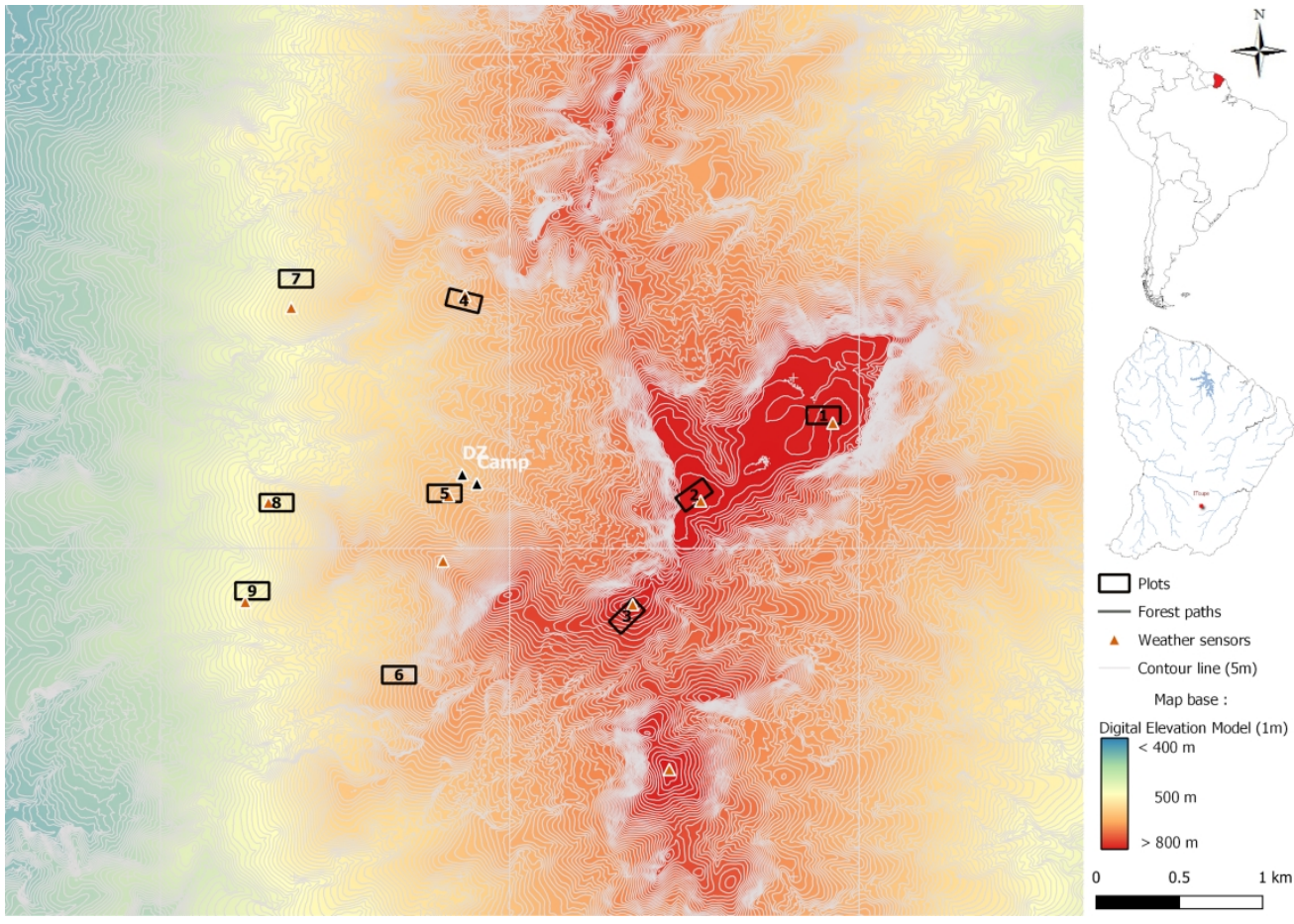




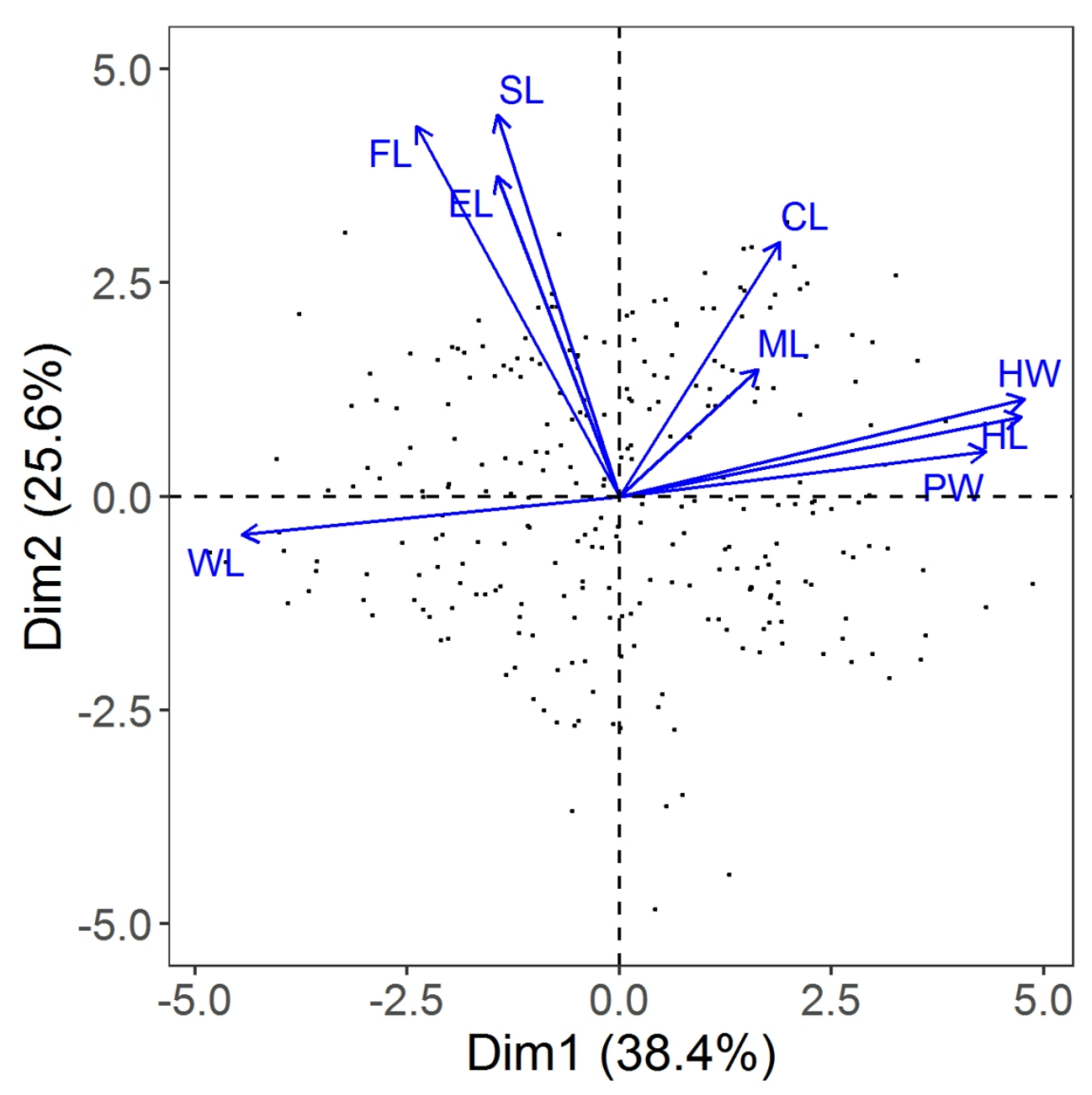




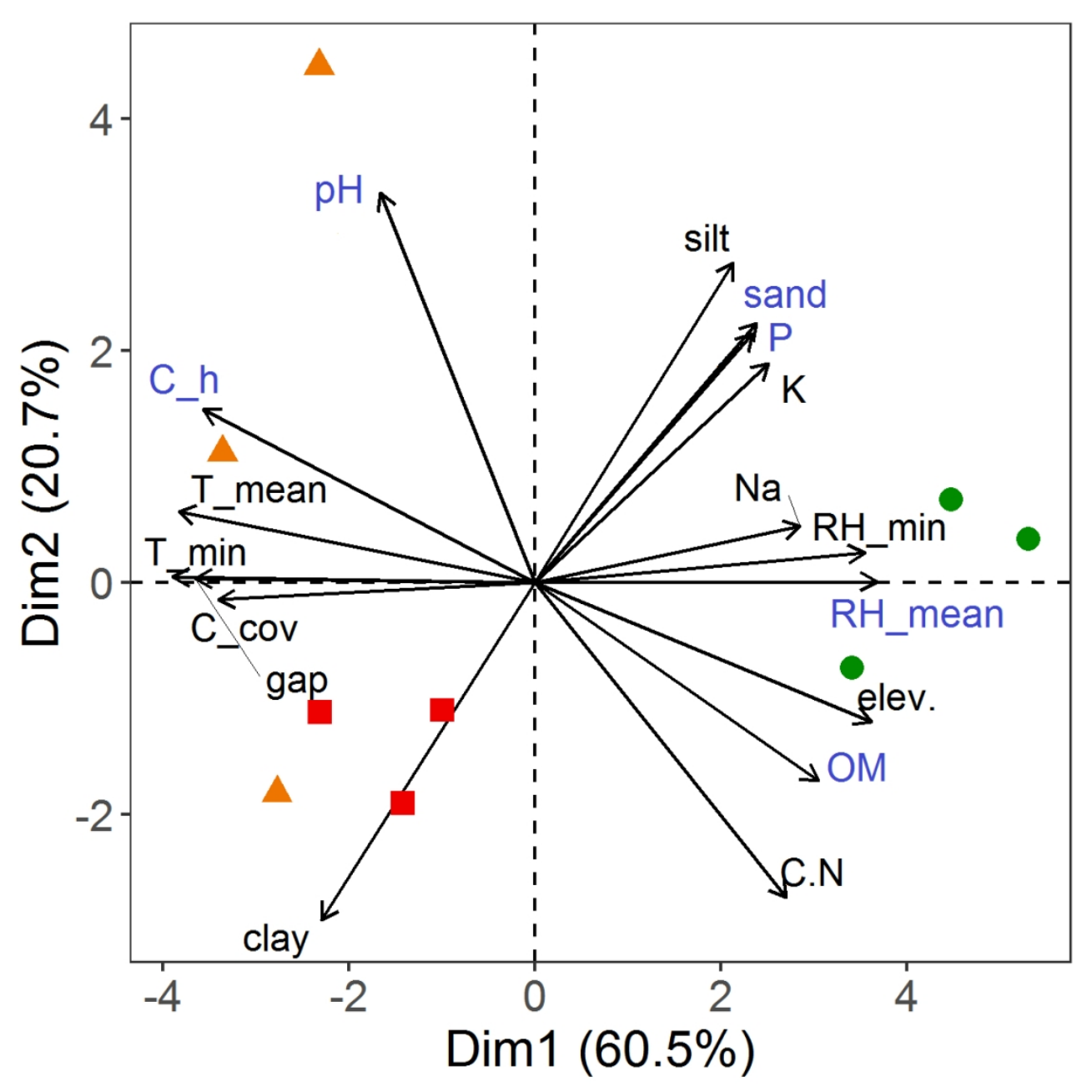

